\title{
A ACADEMIA DE SCIENCIAS JURIDICAS E A TOMADA DO CONVENTO DOS FRANCISCANOS NA CIDADE DE SÃO PAULO
}

\author{
THE ACADEMY OF LEGAL SCIENCES AND THE SEIZURE OF ST. FRANCI'S CONVENT IN THE \\ CITY OF SAO PAULO
}

\author{
Gabriel Antunes de Araujo* \\ Monica Cencic**
}

\begin{abstract}
Resumo:
Neste texto, apresentamos um grupo de manuscritos que revela detalhes da negociação que levou à cessão do edifício do Convento dos Franciscanos, no ano de 1828, à Academia de Sciencias Juridicas de São Paulo, atual Faculdade de Direito da Universidade de São Paulo. Os manuscritos, datados de 1827 e 1828, documentam o processo de escolha do edifício, a comunicação entre o então diretor da Academia (José Arouche de Toledo Rendon), a Secretaria dos Negócios do Império e os representantes franciscanos, bem como os conflitos dessa relação. Pretendemos mostrar, através da análise dos manuscritos, que a entrega do Convento dos Franciscanos ao Curso Jurídico em 1828 constituiu-se mais em uma tomada do edifício do que uma simples cessão voluntária.
\end{abstract}

Palavras-chave: Filologia. Faculdade de Direito. Convento de São Francisco. Século XIX. História.

\begin{abstract}
:
In 1827, São Paulo had its first Law School, the Academia de Sciencias Juridicas de São Paulo, currently Faculdade de Direito da Universidade de São Paulo. However, despite all efforts, there was no building to house the Academy. In order to fix this problem, the Imperial Government and the São Paulo Provincial Governor negotiated the cession of Saint Francis' Convent to host the first Brazilian Law School. Nevertheless, based on extensive original documentation, we will argue, in this paper, that the negotiations were not totally friendly and the Franciscans resisted delivering their building. In this sense, the manuscripts analysed here reveal a hostile takeover rather than a friendly grant.
\end{abstract}

Keywords: Philology. USP's Law School. Saint Francis' Convent. 19th century. History.

1. Introdução

Em março de 1828, as atividades da Academia de Sciencias Juridicas de São Paulo, atual Faculdade de Direito (FD) da Universidade de São Paulo (USP), foram inauguradas em uma sala do Convento dos Franciscanos, no Largo de São Francisco, no

\footnotetext{
* Professor do Programa de Pós-Graduação em Filologia e Língua Portuguesa da Universidade de São Paulo.

** Pesquisadora da Universidade de São Paulo.
} 
centro da cidade de São Paulo. Ainda naquele ano, a Academia se expandiu e veio a ocupar todo o espaço físico do Convento. A Academia de São Paulo foi, junto com a Academia de Sciencias Juridicas e Sociais de Olinda, uma das primeiras instituições de ensino superior laico do Brasil. Oficialmente, os estudos superiores começaram, no Brasil, na chegada da Corte Portuguesa (em 1808), com a criação da Escola de Medicina e Cirurgia, embrião da futura Universidade Federal da Bahia. Em 1934, a Academia, já renomeada Faculdade de Direito, foi incorporada à Universidade de São Paulo. Antes da incorporação à USP em 1934, a Faculdade de Direito era uma unidade autônoma, subordinada ao Governo Imperial (1827-1889) e ao Governo do Estado de São Paulo (1889-1934). Por ser uma das primeiras instituições de estudos humanísticos do Brasil, a Faculdade tomou para si a tarefa de formar a intelligentsia do país (Adorno 1998, Martins e Barbuy 1999, Venâncio Filho 2004), atraindo, para formar seu alunato, a elite jovem brasileira, assim como professores do Brasil e do estrangeiro para formar seus quadros (Araujo et al. 2007).

O objetivo deste texto é divulgar a edição de um grupo de documentos que nos permite refazer o percurso da escolha, da cessão e da ocupação do Convento pelos responsáveis pela instalação da Academia em São Paulo. Mostraremos, também, a posição dos franciscanos em relação à cessão de seu Convento. Os documentos revelam a resistência por parte dos frades e, finalmente, a aceitação, por falta de alternativas, da cessão do edifício.

Os documentos objetos desta pesquisa estão depositados no Arquivo da Faculdade de Direito da Universidade de São Paulo, no Arquivo dos Franciscanos (em São Paulo) e na Biblioteca Nacional do Rio de Janeiro. Há documentos diversos endereçados à Faculdade, entre eles, a correspondência do Ministro Provincial, o chefe dos frades franciscanos na Corte, os ofícios do guardião do Convento, uma carta do sacristão da Igreja de São Francisco e documentos oriundos do Ministério dos Negócios do Império, órgão do Governo Imperial responsável pela implementação e administração da Escola de Direito de São Paulo. Os manuscritos foram editados de forma a preservar suas características lingüísticas e são acompanhados de suas reproduções mecânicas (fac-símiles), as quais se encontram apresentadas no Anexo, após as referências bibliográficas.

O texto está organizado da seguinte forma: na seção 2 (baseados em Nogueira 1953 e em Venâncio Filho 2004) retomaremos o processo de escolha do Convento dos Franciscanos através da correspondência de José Arouche de Toledo Rendon, primeiro diretor da Academia, com o Governo Central. A seção 3 apresentará os documentos enviados pelo Governo Central ao diretor da Escola e o manuscrito do suposto sacristão da Igreja de São Francisco que reclama do incômodo causado pela divisão do edifício do Convento. Em seguida, teceremos algumas considerações finais. 


\section{A escolha do Convento}

Com a expulsão dos jesuítas de São Paulo em 1640, um grupo de religiosos franciscanos se instalou na cidade, naquele mesmo ano, e o Convento de São Francisco e São Domingos foi inaugurado, em 17 de dezembro de 1647 (cf. Leme s/d, Röwer 1941). Com o passar dos anos, mais alguns conventos dos franciscanos foram erguidos nas imediações da cidade de São Paulo: em Itu, em São Sebastião, em Itanhaém, em Santos e em Taubaté. Contudo, no começo do século XIX, não havia muitos frades franciscanos ocupando tais conventos. Dessa forma, diante da escassez de frades residentes no Convento de São Francisco, José Arouche de Toledo Rendon ${ }^{1}$ escolhe este prédio para servir como sede provisória para a Academia. Portanto, o prédio deveria ser desocupado, e os frades levados a outros conventos.

Rendon sugeriu ao Governo Imperial o Convento dos Franciscanos para abrigar a Academia apenas depois de uma inspeção nos outros conventos da cidade. É numa longa missiva ao Ministro Visconde de São Leopoldo, em 20 de novembro de 1827 , que Rendon relata que examinou os cômodos de três conventos de frades, existentes nesta cidade, que são do Carmo, de São Bento e de São Francisco. §O primeiro e o segundo não têm capacidade para nêles se estabelecer o Curso Jurídico; porque, não tendo celas senão nas frentes, estas têm pouca extensão e apenas em cada uma delas se arranjariam três aulas; e para isso seria preciso expulsar os frades e demolir tôdas as celas, para delas e dos corredores formar salões. §Portanto, resta o São Francisco. §Êste convento tem celas na frente e no lado direito. No lado esquerdo está a igreja, e na retaguarda um salão antigo e outro sumamente grande, em paralélogramo, destinado para celas. O primeiro serve sofrivelmente para uma aula, e do segundo se podem formar duas. §No lado direito também está uma boa livraria, que me parece já tem 5.000 volumes (...) (Nogueira 1953: 39-40). Adiante, Rendon conclui: (...) Nessa hipótese [i.é, de se aceitar a sugestão para a instalação no Convento, GAA e MAC], fica interinamente bem o Curso Jurídico em São Francisco, pois o Convento serve bem para um Seminário (Nogueira 1953: 41). Não seria

\footnotetext{
Adepto da causa da independência, foi, em janeiro de 1822, como delegado da Câmara Municipal de São Paulo, enviado ao Rio de Janeiro, em missão junto ao Príncipe Regente, D. Pedro, para solicitar-lhe que desobedecesse aos chamados das Cortes de Lisboa e ficasse no Brasil. Fizeram parte dessa missão, também, o Coronel Gama Lobo e, por parte do Governo Provisório, José Bonifácio de Andrada e Silva. Por decreto de 20 de maio de 1822, foi nomeado comandante das Armas de São Paulo. Feita a Independência e convocada a Assembléia Constituinte, foi eleito deputado por São Paulo (...). Na Assembléia, tomou parte nas discussões em torno da indicação de Fernandes Pinheiro sobre a criação da Universidade de São Paulo. Eleito deputado geral para a legislatura de 1826 a 1829 , não tomou assento e foi substituído pelo brigadeiro José Vicente da Fonseca. Por decreto de 13 de outubro de 1827, foi nomeado diretor do Curso Jurídico de São Paulo, que instalou em $1^{\circ}$ de março de 1828 , nele permanecendo até 1833 , quando, atendendo a insistentes pedidos seus, o governo imperial lhe concedeu exoneração, por decreto de 31 de outubro de 1833 . Faleceu aos 26 de junho de 1834. (http://www.direito.usp.br)
} 
a primeira vez que os franciscanos cederiam um convento para a instalação de cursos ou universidades. Em Bolonha, antes do ano mil, em parceria com os dominicanos, os religiosos abrigaram a primeira universidade local (Campos 1954: 310). Segundo Arouche Rendon, o subaproveitamento e as condições de ocupabilidade do Convento tornavam-no o local ideal para a instalação da Academia, pois, no segundo quartel do século XIX, o Convento contava somente com cinco frades residentes. Rendon, escrevendo ao Ministro de Estado dos Negócios do Império, Ministro Visconde de São Leopoldo, em 9 de julho de 1828, relata que nesta cidade [de São Paulo, GAA e MAC] só existem 5 [franciscanos, GAA e MAC]; e êstes 5 se reduzem ao guardião e 2 frades, porque o $4^{\circ}$ frade é nulo e o $5^{\circ}$ mora fora da cidade, como capelão das Recolhidas da Luz (Nogueira 1953: 52). Assim, à revelia dos frades franciscanos, instala-se uma discussão política de alto nível acerca da utilidade do edifício dos religiosos como futura sede provisória do Curso Jurídico. A carta de Rendon, apesar de sua conhecida religiosidade e cumprimento dos preceitos católicos, demonstra desdém sobre o trabalho religioso dos franciscanos, considerando-o supérfluo.

\section{Análise dos documentos}

Nesta seção, apresentaremos os documentos referentes à questão da ocupação do Convento enviados pelo Gabinete do Ministério dos Negócios do Império, o documento do Ministro Provincial Frei Joaquim de São Daniel e o manuscrito do suposto sacristão Francisco de Paula Leme.

Rendon, em ofício, com data de 20 de novembro de 1827, no qual examina os locais que serviriam para a instalação do curso em São Paulo, afirma ter observado as instalações de três conventos de frades existentes na cidade de São Paulo: do Carmo, de São Bento e de São Francisco, sendo que o primeiro e o segundo não traziam condições para neles se estabelecer um curso jurídico, uma vez que havia poucas celas para as aulas, havendo a necessidade de "expulsar os frades" e demolir as celas, para construir salões. Em relação ao Convento de São Francisco, dá detalhes pormenorizados do que poderia ali ser feito. $\mathrm{O}$ ofício traz ainda o horário em que deveriam iniciar as aulas, a partir das oito da manhã. Pode-se também notar, neste ofício, que Rendon acreditava que a instalação do Curso no convento era provisória, pois supunha que o Imperador iria mandar construir para a Faculdade de Direito um prédio próprio, assim como para as outras faculdades.

No dia 27 de novembro de 1827, o Ministro Pedro de Araújo Lima solicita ao vice-presidente da Província de São Paulo, Luís Antônio Neves de Carvalho, que se entenda com os Religiosos Franciscanos para se abrir a aula do primeiro anno em uma sala que tenha as dimensões necessárias no edificio que elles occupaõ, e para darem as casas que for [e]m precisas para o Archivo, e mais serviços do mesmo estabelecimento 
(documento Ami 1828-31/0023, ${ }^{2}$ Araujo et al. 2007: 156). Por ordem imperial, o futuro do Convento estava decidido. Rendon desconhece a intensa troca de correspondência entre o Governo Imperial e a alta hierarquia franciscana sobre a cessão do edifício, pois, devido às mudanças no Gabinete Ministerial (Araújo Lima assumiu o cargo em 20 de novembro de 1827, em substituição a José Feliciano Fernandes Pinto, o Visconde de São Leopoldo), Rendon escreve novamente ao Ministro dos Negócios do Império, possivelmente, antes de receber o ofício de 27 de novembro e, outra vez, reitera que o Convento dos Franciscanos seria o local provisório ideal para o Curso Jurídico. Não obstante, o caráter da ocupação interina do edifício, como sugerido por Rendon, seria ignorado em todos os ofícios subseqüentes remetidos pela Corte.

Se a escolha da região para a instalação do Curso Jurídico ficou a cargo do Visconde de São Leopoldo, com a lei de 11 de agosto de 1827, foi Rendon quem primeiro traçou todas as diretrizes para que o curso funcionasse no Convento dos Franciscanos, o que se verifica nos ofícios de 20 de novembro de 1827 e de 2 de dezembro de $1827 .{ }^{3}$ Dois ofícios respondem a eles: AMI-1828-1831/001 (Araujo et al. 2007: 156), datado de 27 de novembro de 1827, assinado por Pedro de Araújo Lima, o Marquês de Olinda, remetido ao Vice-Presidente da Província de São Paulo, pedindo-lhe as providências necessárias para que sejam iniciadas as aulas do primeiro ano dos Cursos Jurídicos, e AMI-1828-1831/007 (Araujo et al. 2007: 158), ofício datado de 14 de janeiro de 1828, assinado por Pedro de Araújo Lima, comunicando o envio de um ofício ao Imperador, no qual é mencionado que os Religiosos Franciscanos concordaram em ceder seus imóveis para o funcionamento dos Cursos Jurídicos em São Paulo.

Thomas Xavier Garcia de Almeida, presidente da Província de São Paulo, enviou a Pedro de Araújo Lima um ofício, datado de $1^{\circ}$ de janeiro de $1828 .{ }^{4}$ Nele, faz referência à portaria de 27 de novembro no qual o Governo é instruído a se entender com os religiosos franciscanos na questão da cessão do Convento. Após percorrer várias dependências de prédios religiosos, o Presidente da Província conclui que as casas no nível de entrada do convento de São Francisco, ao redor do claustro são melhores para as aulas, já que as medidas dos cômodos eram bem avantajadas, embora precisassem de alguns pequenos reparos. Salienta, ainda, que os religiosos em nada se opunham, muito pelo contrário, sentiam-se satisfeitos por contribuírem para com o interesse nacional.

\footnotetext{
2 O código refere-se ao documento da brochura Avisos do Ministério do Império (AMI), referente aos anos de 1828 a 1831, imagem digitalizada número 23 (cf. Cencic 2009), depositada no Arquivo da Faculdade de Direito.

3 Há uma nota, no final da cópia, dizendo: "Este officio nos autos tem a data de 10 dezembro 1827 ".

4 Ofício não encontrado no arquivo da FD.
} 
Em ofício datado de 2 de março de $1828,{ }^{5}$ Thomas Xavier Garcia de Almeida comunica a Pedro de Araújo Lima ter havido a "feliz inauguração" com solene ato de abertura da Academia do Curso Jurídico, no qual houve a récita da Oração de Sapientia pelo lente José Maria Brotero na aula do primeiro ano, estando ainda tudo em ordem no que dizia respeito às "casas" do arquivo, quarto do porteiro e do contínuo, faltando apenas arranjar-se a "casa" da livraria no antigo refeitório dos franciscanos. Assegura que tudo ficou na melhor ordem e que estão independentes do Convento habitado pelos religiosos. Comenta que enviaria um "individuado desenho" das dependências e que foram nomeados para porteiro o praticante da junta da fazenda, José Joaquim Rodrigues ${ }^{6}$ e, para contínuo, José Joaquim de Moraes. ${ }^{7}$

José Arouche de Toledo Rendon envia um ofício ${ }^{8}$ a Pedro de Araújo Lima, em 11 de março de 1828. Na ocasião, menciona um ofício anterior de 9 de março ${ }^{9}$ comunicando a abertura do curso Jurídico, além de relatar a necessidade de haver sinais para o toque das aulas. Existindo no convento já um, crê ser ele possível tanto para o uso dos religiosos quanto para o Curso Jurídico. Dessa forma, Rendon diz ter pedido ao Padre Guardião que desse ordens ao sineiro dos religiosos, o qual o diretor não sabia se era donato ou escravo, para fazer os sinais das aulas do curso jurídico. Rendon salienta que o guardião "se portou muito bem" e se encarregou de tudo, principiando ter exercício na primeira aula, e que seria bem justo que se desse aos frades, como esmola, o salário destinado a um sineiro, "pelo bom comportamento que tem tido". As ordens incluíam a tarefa de badalar, por dez minutos, o sino grande às 7 h30 da manhã e que às 8 horas houvessem 8 badaladas, repetindo-se às nove, quando acabasse a lição; à noite, tocassem os tristes ou silêncio um pouco depois de Ave-Marias, e às nove tocassem os alegres de ambos os couros nos sinos pequenos.

Rendon envia, em 9 de junho de 1828, outro ofício, para Pedro de Araújo Lima, informando-lhe que o Curso Jurídico estava ocupando a parte dos baixos do Convento de São Francisco porque os frades ainda mantinham a sacristia, o jazigo e a cozinha. Para o Curso, ficaram duas salas grandes e uma pequena destinada ao curso de geometria e língua francesa, mais duas salas pequenas, uma para o porteiro e outra para os contínuos, além de uma sala maior para a secretaria, e o refeitório para o uso da biblioteca. No entanto, o diretor não achava razoável o uso do refeitório para aquele fim, pois o ambiente era úmido em razão de ser o terreno exterior mais alto que o solo interno. Sendo assim, pede outro lugar para os livros e mais duas salas para as aulas do Curso Jurídico,

Ofício não encontrado no arquivo da FD.

Não há menção a José Joaquim Rodrigues nos ofícios editados (Cencic 2009).

Referência em AMI-1828-1831/0067.

Ofício não encontrado no arquivo da FD.

Ofício não encontrado no arquivo da FD e nem no material dos franciscanos. 
para não ter que ministrar as aulas no período da tarde. Propõe ao governador, então, que os frades deixassem o campo livre porque lhes sobejavam casas em outras vilas da Província, sendo que, à época, havia seis conventos da Ordem Franciscana: nas vilas de Itu, Santos, São Sebastião, Itanhaém e Taubaté, além do Convento em São Paulo. Rendon aponta ainda que, na Província havia, segundo as "taboas estatisticas", dezessete frades, sendo seis em São Paulo, cinco em Santos, um em Itu, outro em Taubaté, três em São Sebastião e um em Itanhaém. Em seguida, afirma que qualquer um dos Conventos, com exceção do de São Sebastião, por ser pequeno, acomodaria bem dezessete frades. Porém não deixa de salientar que via em São Paulo apenas cinco religiosos: um guardião e dois frades no convento, o quarto frade que era "nulo"10 e o quinto que morava fora da cidade, como capelão das Recolhidas da Luz. Uma vez indo morar em outro convento, Rendon diz que não deixariam patrimônio para trás e em qualquer parte achariam o mesmo que no Convento de São Francisco. Ao caminhar para a parte final do ofício, Rendon sugere que se o imperador fizesse tudo conforme havia sido proposto, ou seja, reunir os religiosos em uma só casa, o soberano estaria obrando política e religiosamente, pois o Estado teria "casas" não só para a Faculdade Jurídica, mas também para as aulas menores da Academia, as quais seriam muito bem inspecionadas, sem contar a economia das despesas interinas que se tornariam supérfluas.

Em 13 de agosto de 1828, José Clemente Pereira envia um ofício ${ }^{11}$ ao Senhor Provincial dos Menores Observantes da Província da Conceição. Nele, pedia que o Provincial informasse se havia inconveniente na cessão voluntária de todo o Convento para ocupá-lo com as aulas do Curso Jurídico.

O ofício tratando da total entrega do Convento dos Franciscanos ao diretor do Curso Jurídico, datado de 16 de agosto de 1828, remetido pelo Frei Joaquim de São Daniel ao Imperador, sobreviveu no Arquivo da FD apenas na forma de uma cópia datilografada. Em 1903, o restaurador do Arquivo, Julio Barros, anotou no documento que o original não havia sido devolvido, embora não mencione o local onde se encontra ou o nome do responsável pelo guarda do original. Todavia, encontramos uma versão do original na Biblioteca Nacional do Rio de Janeiro (Anexo: documento 1). O documento foi enviado pela alta hierarquia franciscana. $\mathrm{O}$ ofício do clérigo menciona que, no dia 13 de agosto de 1828, a Secretaria de Estado dos Negócios do Império informara sobre a necessidade da cessão de todo o edifício do Convento. Assim, mediante ordem imperial, nada restava aos franciscanos senão entregar o prédio à pessoa designada pelo Governo Imperial. O discurso empregado no documento revela que a transferência do edifício deuse pela impossibilidade de contrariar uma ordem imperial. O religioso emprega as palavras

\footnotetext{
10 Rendon não especifica outros detalhes sobre este franciscano.

11 Ofício não encontrado no arquivo da FD.
} 
e expressões 'manda' (linha 1), 'mandou instituir' (linha 6), 'soberana declaração' (linha 9), 'Ordens' (linha 14), porquanto, dessa forma, evidencia-se o caráter imperativo do desejo imperial. Ademais, o Ministro Provincial declara, de forma retórica, que os franciscanos nada perderiam com a cessão do Convento, já que nada lhes pertencia neste mundo. ${ }^{12}$ Há também, neste documento, uma longa anotação de terceiros:

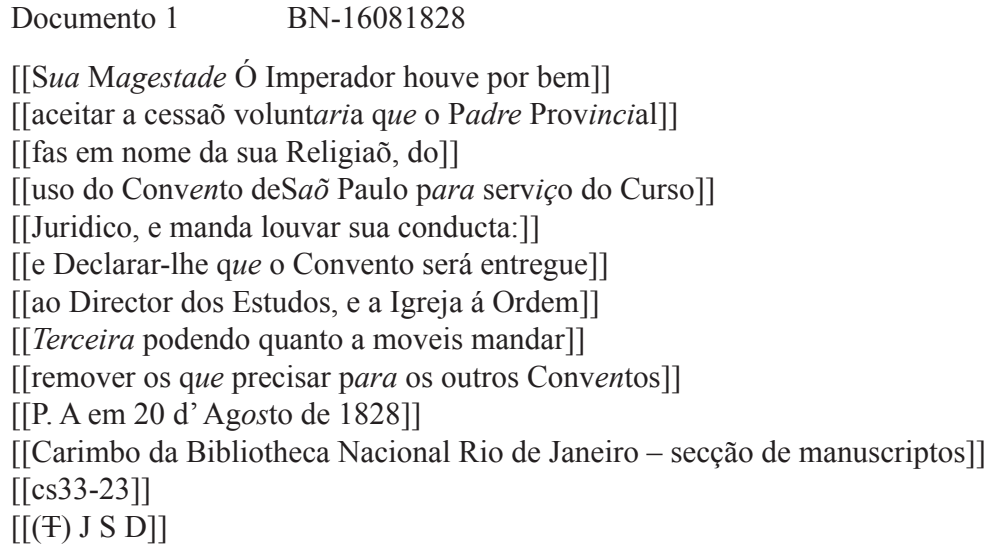

Senhor.

\section{Manda Vossa Magestade Imperial}

em Portaria expedida pela Secretaria d' Estado dos Negocios do Imperio datada em 13 do corrente Agosto Declarar-me, que hé mui acanhada, e insufficiente a parte já cedida do Convento de Sã̃ Francisco na Cidade de Sã̃ Paulo para n'ella se estabelecerem todas as Aulas necessarias em o Curso-Juridico, que

12 Normas de transcrição:

1: A transcrição será cotejada com a reprodução fac-similar; 2: as características do original serão preservadas ao máximo, incluindo as características grafemáticas (forma e posição de diacríticos, separação dos vocábulos, sinais de pontuação, grafia de palavras, uso de maiúsculas e minúsculas); 3: as abreviaturas serão desenvolvidas e assinaladas em itálico; 4: as intervenções feitas por editores, copiadores ou arquivistas serão colocadas entre colchetes duplos antes da transcrição do documento; 5: os eventuais erros de ortografia e grafias diferentes de uma palavra serão mantidos; 6: nos casos de ilegibilidade, a palavra será marcada com 'ilegível' entre colchetes: [ilegível]; 7: a leitura por conjectura (quando houver um problema na grafia da palavra que torna parte ou todo ilegível, embora a recuperação da palavra seja possível, por conjectura) sem possibilidade de falha será assinalada com o uso de colchetes simples, como em 'justi[ça]'. No caso de leitura duvidosa, empregar-se-á parênteses no trecho em que possa haver outras interpretações ou nos quais, embora legíveis, haja dúvidas em relação à interpretação, como em 'minis(tro)' — que também pode ser 'minis(terio)'. A escrita entre linhas será assinalada por diples (<exemplo $>$ ); 8: o texto editado será numerado justalinearmente de forma contínua, de $5 \mathrm{em} \mathrm{5}$, ao lado do texto editado); 9: quando se tratar de documento com mais de um fólio, o número de fólios será indicado mencionando-se também se se trata do fólio recto ou verso. $\mathrm{O}$ fólio recto será indicado apenas com a numeração arábica, como em 1 , e o fólio verso receberá a numeração mais a letra minúscula $v$, como em $1 v ; 10$ : os números que se referirem às datas (por exemplo: $1^{\circ}$ de Junho de 1860), sejam eles cardinais ou ordinais, serão transcritos como se apresentarem nos manuscritos originais. Com exceção quando se tratar de abreviações para nomes de meses (por exemplo, 9 bro $>$ Novembro); 11: as assinaturas simples e/ou as rubricas do punho de quem assina serão sublinhadas (cf. Spina 1997, Cambraia 1999, Bellotto 2000 e 2002, Oliveira 2005, Araujo et al. 2007, entre outros). 
alí se mandou instituir: e que se torna indispensavel a cessaõ completa de todo o edificio para melhor commodo d'aquelle interessante Estabelecimento Publico. Em consequencia pois desta Soberana Declaraçaõ a Communidade dos Franciscannos, que por força do Santo Instituto, que professa nada possúe proprio, e quanto goza hé devido á Piedade dos Povos, nada tem que oppor a hua urgencia de Estado de tal natureza, como hé esta; e só me cumpre na qualidade de Chefe, e Representante desta Religioza Corporaçaó receber do Governo de Vossa Magestade Imperial as Ordens, e convenientes Instrucçoens sobre o modo, estado do edificio, e a pessoa, a quem se hade fazer a entrega. Convento de Santo Antonio da Corte do Rio de Janeiro em 16 d' Agosto de 1828

Frei Joaquim de Saõ Daniel Ministro Provincial

No dia 20 de agosto de 1828, o Ministro Imperial José Clemente Pereira responde, em nome do Imperador, ao líder dos franciscanos, Frei Joaquim de São Daniel. Nos Arquivos da FD há somente uma cópia datiloscrita do ofício original. Uma anotação de terceiros na cópia (Anexo: documento 2) informa que o original e um segundo documento estavam 'em mãos de Secretário Doutor Júlio Maria, e por ele entregues ao Doutor (...) Candido Motta', ${ }^{13}$ embora não tenham sido devolvidos ao arquivista da FD. No documento, Pereira agradece ao Frei Joaquim de São Daniel a cessão voluntária do edifício e the informa que o Diretor do Curso Jurídico assumirá o Convento. No entanto, todas as alfaias do Convento e a Igreja do mesmo edifício deveriam continuar com os franciscanos.

Documento 2 ami 1828-31/0027

[[20 Agosto de 1828]]

[[Carimbo do Archivo da Faculdade de Direito, com rubrica Barros]]

[[em vermelho: Documento Numero 10 - Copia do Doutor]]

[[Observaçaõ:]]

[[ Os documentos sob numeros 10 e 10v,]]

[[que estavam em maõs de Secretario Doutor Julio Maria,]]

[[e por ele entregues ao Doutor (Ipemar), di(go) ao Doutor]]

[[Candido Motta, naõ me foram devolvidos.]]

[[O Archivista]]

[[Julio de Barros]]

[[Copia de Documento numero 10 de (Heses) Geraldo (I) Leite]]

Foi presente a sua Magestade o Imperador a resposta que Vosso Padre Reverendissima deu ao avizo de 13 do corrente. sobre a necessidade da cessão de todo o Convento de São Francisco,da Cidade de São Paulo,para as aulas do Curso Juridico,ali instituido:E louvado o Mesmo Augusto Senhor o digno procedimento de Vosso Padre Reverendissima na cessão voluntaria que fáz do sobredito Convento em nome da sua religiosa corporação,para o ser

\footnotetext{
13 Trata-se do professor da FD, Cândido Nanzianzeno Nogueira da Mota.
} 
viço publico: Ha por bem Acceita-la, e Declarar, que seja entregue o convento ao Director dos Estudos,e a Igreja á Ordem Terceira, podendo Vosso Padre Reverendissima quanto aos moveis, e alfaias da mesma Igreja, determina:

a sua remoção para onde julgar conveniente.O que participo a Vosso Padre Reverendissima para sua intelligencia. Deos Guarde a Vosso Padre Reverendissima. Paço em 20 de Agosto de 1828. - Jozé Clemente Pereira. Senhor Ministro Provincial dos Menores Observantes."

Já no dia 21 de agosto de 1828, o Ministro Pereira envia ofício ao vicepresidente da Província de São Paulo comunicando-lhe que o Diretor do Curso Jurídico deveria assumir a parte restante do Convento (Anexo: documento 3). Novamente, a linguagem empregada pela autoridade imperial encobre qualquer disputa ou insatisfação. Segundo o ofício, o restante do Convento havia sido 'voluntariamente cedido' pelo Provincial Frei Joaquim de São Daniel.

Documento 3 ami-1828-1831/0025

[[21 Agosto de 1828]]

[[Carimbo do Archivo da Faculdade de Direito, com rubrica Barros]]

[[Numero 9]]

[[Grifos sob Ministro Provincial dos Menores Observantes da, linha 1; Director, linha 9; que tomasse conta, linha 9; do Convento, linha 10; a Igreja á Ordem, linha

10; Terceira, para della cuidar, linha 11]]

[[Marca do fabricante do papel: JOHN GREEN 1825]]

$[[+]]$

Tendo o Ministro Provincial dos Menores Observantes

da Provincia da Conceiçaõ voluntariamente cedido, em nome da

sua Religiosa Communidade para uso do Curso Juridico da

Cidade de Saõ Paulo, o resto do Convento de Saõ Francisco, por

não ser sufficiente a parte anteriormente cedida para o mes-

mo fim Manda Sua Magestade o Imperador, pela Secreta-

ria d' Estado dos Negocios do Imperio, participar ao Vice-

Presidente da Provincia de Saõ Paulo que na data desta se ordenou ao Director do Curso Juridico que tomasse conta do Convento; e que devendo entregar-se a Igreja á Ordem Terceira, para della cuidar, e manter com decência o culto divino, cumpre que o mesmo Vice-Presidente o faça constar á referida Ordem para sua intelligencia. Palacio do Rio de Janeiro em 21 d' Agosto de 1828.

$\underline{\text { Joze Clemente Pereira }}$

Em 30 de agosto de 1828, Frei Joaquim de São Daniel, ministro provincial, juntamente com outros franciscanos, remete um ofício ao guardião do convento de São Francisco, Frei Joze de São João Chrisostomo, solicitando, com urgência, o inventário dos móveis úteis da Igreja e uma lista das alfaias, e que também distribua os escravos para outros conventos franciscanos (Anexo: documento 4). Na linha 17 do documento, 
Frei Joaquim de São Daniel, expressa claramente a sua posição em relação à cessão do Convento: trata-se de obedecer uma ordem expressa da Majestade Imperial.

Documento $4 \quad$ arquivo dos franciscanos

[[Sã̃ Paulo]]

Tendo Sua Magestade O Imperador feito constar pela Secretaria d' Estado dos Negocios do

Imperio em Portaria datada $\mathrm{em}=13=$ do corrente Agosto, ao Padre Provincial que se tornassem

indispensavel a cessaó de todo o Convento de Nosso P(atrono) Saõ Francísco da Cidade de Sã

Paulo para o conveniente arranjo das Aulas necessarias ao Curso-Juridico, que alí se mandou

estabelecer, acanhado por extremo na parte d'aquelle Edifício já cedida: e, convindo muito que hua

Corporação Religiosa seja a primeira em acodir ás necessidades-Publicas, e se preste com todas as

forças ao bem do Estado, a que tem a honra de pertencer: Ordena-se a Vossa E(xcellencia), Senhor

Ex-Leitor Frei Joze de Sao Joaõ Chrisostomo, Guardiaõ actual do mencionado Convento, que em

conformidade das Ordens ulteriores do Minist(e)rio trate quanto antes d' inventariar os moveis uteis

do Convento, e as alfaias da Igreja: deligenceie depois obter dos Nossos Carissimos Irmaõs Terceiros hú lugar, ou Caza no seo Edifício, em que tudo se conserve em deposito, e boa guarda,

atheque competentemente informados com presteza, se ordene d'aqui sem demora o destino, que

os moveis, e as Alfaias devem ter: destribúa os Escravos com igualdade pelos trez Conventos D'

Ytú, Santos, e Conceição, de maneira que, sendo estes cinco, fique Ytú com dois, Santos dois, e Conceiçaó hum, e, sendo seis, váõ dois para cada hú destes Conventos $=$ coeteris paribus $=$ :

e despido assim o Convento, faça por ultimo entrega do casco aos Director dos Estudo: a Igreja porem,

deixando n' esta u(n)icamente as Imagens com os seos adornos do commum, entregará solemnemente

á Mesa da Veneravel Ordem Terceira, podendo asseverar-lhe, que o faz em consequencia d'expressa Determinação do Governo de Sua Magestade Imperial. Rio de Janeiro em Mesa aos $=30=$ d'Agosto

de 1828 .

Assinados

$\underline{\text { Frei Joaquim de Saõ Daniel }}=$ Ministro Provincial

Frei Manuel da Expectaçaõ $=$ Custodio

Frei Carlos das Mercez - = Dif(inid)or

Frei Mauricio da Encaranaçaõ = Dif(inid)or

Frei Joaquim de Saõ Jeronymo = Dif(inid)or 
Frei Henrique de Santa Anna = Dif(inid)or

Em 11 de setembro de 1828, o diretor do Curso Jurídico envia um ofício ${ }^{14}$ a José Clemente Pereira confirmando o recebimento do documento de 21 de agosto do Provincial, relatando a cessão do Convento em nome da religiosa comunidade. Diz a José Clemente que logo cumpriria sua obrigação assim que os frades deixassem a casa. Relembra ainda a necessidade de um sineiro para os sinais das aulas ou mesmo a hipótese de fazer "uma convenção econômica" com os Terceiros e, caso não houvesse disponibilidade, solicitaria ao Governo da Província.

Em ofício de 11 de outubro de $1828,{ }^{15}$ Rendon escreve a José Clemente confirmando o recebimento de ofício de 27 de setembro para fazer constar ao professor de língua francesa, Augusto Candido da Silveira Pinto, que o Imperador ordenava as expedições das ordens necessárias para a Junta da Fazenda da Província de São Paulo pagar-lhe uma gratificação anual, igual ao ordenado que recebiam os demais professores públicos de estudos preparatórios do curso jurídico, desde o dia em que entrou no magistério. Confirma que passou a participar o acontecido ao professor. Ainda acrescenta no ofício que o convento não havia sido entregue, e nem a Igreja à Ordem Terceira, dizendo ignorar os motivos que fizeram retardar o cumprimento "daquela saudável resolução".

Não obstante as ordens imperiais e o consentimento do chefe dos franciscanos, a entrega efetiva do Convento não foi imediata. No dia 27 de outubro de 1828, Pereira escreve ao Vice-presidente da Província, para garantir que a entrega do Convento ao Diretor do Curso Jurídico ocorra sem demora (Anexo: documento 5). O teor da carta resume toda a discussão em torno da cessão do edifício, ainda que o emprego de certos advérbios revele uma impaciência crescente com o assunto. No documento, a entrega deveria ocorrer 'imediatamente', na 'conformidade' da ordem imperial, uma vez que 'nenhuma' dificuldade poderia embaraçar a conclusão da entrega já que a cessão do prédio era decorrente do franco oferecimento do Ministro Frei Joaquim de São Daniel, cuja generosidade já havia sido lembrada em carta de agradecimento (Anexo: documento 6). Portanto, não havia motivos para o prolongamento da questão.

Documento 5 ami1828-31/0049

\section{[[Registado Ferreira $]]$}

\section{[ilegível]}

(Sua) Magestade o Imperador Houve por bem [ilegivel]

(ar) em Portaria da data deste que [ilegivel]

\footnotetext{
14 Ofício não encontrado no arquivo da FD.

15 Ofício não encontrado no arquivo da FD.
} 
(dessa) Provincia fizesse entregar sem demora (a Vossa Senhoria) [ilegivel] Convento de Saõ Francisco para o serviço das Aulas

(na) conformidade das ordens expedidas em 21 de Agosto deste anno. O que participo a Vossa Senhoria para sua intelligencia.

Deos Guarde a Vossa Senhoria Paço em 27 d' Outubro de 1828

Joze Clemente Pereira

Senhor José Arouche de Toledo

Rendon

Documento $6 \quad$ ami 1828-31/0055

[[O original não foi devolvido ao Archivo $]]$

[[copia de Geraldo Leite-(Heses):]]

[[rubrica de Julio Barros]]

[[Archivista]]

[[Carimbo do Archivo da Faculdade de Direito, com a rubrica Barros]]

Numero

$[[11]]$ de $[[$ Novembro $]]$ de $19[[<1828>]]$

[[CÓPIA.-“Sua Magestade o Imperador Ha por bem que o Vice Presidente da Provincia de São Paulo faça verificar imediatamente a entrega do Convento de São Francisco da Cidade de São Paulo ao Director do Curso Juridico da mesma Cidade, na conformidade do que se lhe ordenou em Portaria de 21 d'Agosto deste anno; cortando por quaesquer difficuldades que se lhe offereção, porque nenhuma deve embaraçar a conclusão da entrega, depois do franco offerecimento que fez o Ministro Provincial dos Menores Observantes da Provincia da Conceição, no seu Officio, por copia incluso, e que foi acceito e agradecido pela Portaria que tambem se remette. O que assim se participa pela Secretaria d'Estado dos Negocios do Imperio ao referido Vice Presidente para sua intelligencia e execução. Palacio do Rio de Janeiro em 27 d'Outubro de 1828. Joze Clemente Pereira". No verso: "Cumpra-se, e registre-se. Palacio do Governo de São Paulo 11 de Novembro de 1822. Ornellas".]]

Na mesma data, José Clemente Pereira envia um ofício ao Senhor Provincial dos Menores Observantes da Província da Conceição. ${ }^{16}$ Refere-se a um ofício de 11 do corrente em que o diretor do Curso Jurídico da cidade de São Paulo reclama de ainda não estar em posse do Convento, salientando o prejuízo pela demora. Pede urgente participação para que o Convento seja desocupado. No entanto, Frei José de São João Chrizostomo explica ao vice-presidente de São Paulo as razoes que justificam a demora na entrega do Convento e manifesta sua dúvida sobre o fato de a livraria (biblioteca) ficar

16 Ofício não encontrado no arquivo da FD. 
ou não para o Curso. O ofício é datado de 13 de novembro de 1828 e, inicialmente, retoma o assunto do ofício do vice-presidente em 12 de novembro, no qual pedia ao diretor do curso jurídico a entrega do Convento, sine mora. Afirma que logo após ter recebido o ofício, teve respeito e submissão e lançou mão de todos os meios competentes para que se efetuasse a exigida entrega, procedendo mudanças em dois altares, um da enfermaria e outro do jazigo, estando estes separados em peças no corredor da sacristia. Também operou desarranjos nas celas do Convento, removendo ornatos para certos cantos e esconderijos da Ordem Terceira. Relata que faltava muito pouco para concluir o seu serviço, no entanto por ter estado doente por muitos dias, não querendo sair “de sua casa” para medicar-se em casa alheia, e cria que o Imperador certamente entenderia tal ato vindo de homens que haviam dado provas tão claras de patriotismo. Dessa forma, o guardião acreditava estar perdoado do crime de insubordinação. A seguir, expõe uma dúvida em relação aos móveis do Convento. Sabendo que deveria remover todos os móveis, tinha dúvidas em relação à biblioteca (ou livraria), a qual também considera mobiliário, no entanto ela se achava unida e franqueada à Biblioteca Nacional, não sendo destinada para utilidade pública por um acordo entre o Governo da Província de São Paulo e um provincial dos franciscanos, registrado em documentos. Uma vez tendo apresentado as razões incompatíveis "com tanta aceleração" que dele se exigia, reafirma ainda novamente que nunca deixara de se submeter à "inteira subordinação" que se devia tributar às determinações do Imperador.

Finalmente, no dia 2 de dezembro de 1828, por meio de ofício remetido ao Diretor do Curso Jurídico pelo guardião do Convento dos Franciscanos, Frei José de São Chrizostomo, a entrega do edifício é marcada para o dia 3 de dezembro, às quatro horas da tarde (Anexo: documento 7). Novamente, os termos empregados no documento denotam o caráter autoritativo das ordens recebidas (linha 1: Imperiais ordens; linha 5: despejo; linha 6: he de meu dever) e a necessidade de se fazer cumpri-las em nome do dever.

Documento 7

ami $1828-31 / 0071$

[[2 Dezembro 1828]]

[[Carimbo do Archivo da Faculdade de Direito, com rubrica Barros]]

[[Duas vezes $\mathrm{X}$ em azul]]

Em consequencia das Imperias ordens que me foraõ transmittidas pelo meu Provincial, e pelo Illustrissimo, e Excellentissimo Governo desta Provincia tendo em pregado os meios necessarios, que estavaõ aomeu alcance para o despejo deste Convento; e tendo concluido este negocio, resta me agora e he de meu dever, participar a Vossa Excellencia que pode vir tomar posse do dito Convento para cuja entrega me achará prompto nodia tres doCorrente pelas quatro horas da tarde.

Deos Guarde aVossa Excellencia Convento 
de Saõ Francisco da Imperial Cidade deSaõ Paulo aos 2 de Dezembro de 1828.

Frei Ioze de Saõ Chrizostomo

Illustrissimo e Excellentissimo

Senhor Director do

Curso Juridico

Todavia, a carta do Guardião dos Franciscanos encadeou o envio de um ofício legalista, remetido pelo novo guardião do Convento, o diretor do Curso Jurídico, Arouche de Toledo Rendon, ao Vice-presidente da Província de São Paulo, Manuel Joaquim de Ornellas (documento AmI/1828-31/0073. Anexo: documento 8). Nesse documento, o novo guardião anuncia a desocupação do Convento e requer, por parte do vice-presidente, o envio de um funcionário da Província para documentar a entrega do Convento, averiguar as reais condições do edifício e providenciar cópia dos autos para os interessados, a saber: a Fazenda Provincial, a Secretaria do Curso Jurídico e ao Imperador. Solicita, igualmente, o fechamento da porta de comunicação do Convento com a Igreja, de modo que a cessão do Convento se faça com 'Legalidade e clareza'.

Documento 8 ami 1828-31/0073

[[Carimbo do Archivo da Faculdade de Direito, com rubrica Barros]] [[Duas vezes X em azul]]

Ao Vice Presidente

Illustrissimo e Excellentissimo Senhor

Hontem atarde recebi huma Carta do Guardiaõ deSaõFrancisco annunciando-me que o Convento está despejado, econvídando-me para vir receber hoje pelas 4 horas datarde.

Tenho em consequencia de ponderar aVossa Excellencia que aquella Casa fica pertencendo à Naçaõ, aquem tambem pertence oEstabelecimento do Curso Juridico epor $<$ isso $>$ (bem) (diga) o Seo (para) recebimento deve Ser pelo Almoxarife deOrdem do Governo da Provincia Por(isso) <Porque $>$ epara que inda Sefaça com Legalidade eclaresa, eu rogo aVossa Excellencia queira (provideneiar) $<$ dar Suas Ordens $>$ para que o Almoxarife com hum Official da Fasenda vaõ receber o convento, fasendo disso hum Auto, ehum Inventario detodas equaes quer movéis que ali se acharem. Supponho, Segundo disem, que o Inventario Será breve, porque o Padre Guardiaõ tudo mudou edepositou naOrdem Terceira: Como quer que Séja Convem o Inventario ou Seja para Constar o que ficou, ou para provar que nada deixaraõ. Feito isto as Chaves devem Ser entregues ao Porteiro do Curso Juridico, trancando-se as portas deCómunicaçaõ com a Igreja, eCoro. Tambem rogo aVossa Excellencia que Ordene ao Almoxarife que o Inventario eAuto de recebimento Seja em triplicado, para ficar hum na Contadoria da Fasenda, 
outro na Secretaria do Curso Juridico, eo terceiro (Ser remmettido) $<$ Subir (aPresença) (M) a>

de Sua Magestade (pelo) Ministro do Imperio <Imperial>; entregando-se me os (dois), e Levan-

do (aquele) $<_{0}$ terceiro $>$ à Junta da Fazenda. Deos Guarde Sã̃ Paulo 3 de Dezembro

de 1828.

Illustrissimo eExcellentissimo Senhor Vice Presidente Manoel Joaquim de Ornellas

Como solicitado, Manoel Joaquim de Ornellas enviou um funcionário, Manoel Barboza da Silva, acompanhado do almoxarife Antonio Maria Quartin, que inventariou os bens do Convento e, no dia 6 de dezembro de 1828 (documento AMI 1828-31/0081. Anexo: documento 10), passado quase um ano desde a escolha do edifício, encerrou o processo de cessão do antigo Convento dos Franciscanos ao Curso Jurídico de São Paulo com a expedição do 'auto de Inventário' (documento AMI 1828-31/0087 e 0087v. Anexo: documentos 11 e $11 v$ ).

Documento 9

ami 1828-31/0081

[[6 Dezembro 1828]]

[[Carimbo do Archivo da Faculdade de Direito, com rubrica Barros]]

Illustrissimo e Excellentissimo Senhor

Incluso achará Vossa Excellencia em duplicado o autto o autto de Inventario, que se lavrou por occasiaõ do recebimento do Convento de Saõ Francisco pelo Almoxarife da Fazenda Nacional conforme Vossa Excellencia me requereo em seo officio de 3 do corrente.

Deus Guarde a Vossa Excellencia Palacio do Governo de Saõ Paulo 6 de Dezembro de 1828 .

Manoel Joaquim de Ornellas

Senhor Marechal Joze Arouche de Toledo Rendon

Documento $10 \quad$ ami 1828-31/0083

[[3 Dezembro 1828]]

[[Carimbo do Archivo da Faculdade de Direito, com rubrica Barros]]

[[Duas vezes X em azul]]

Aos tres dias do mez de Dezembro de mil oito centos e vinte oito nesta Cidade de Saõ Paulo em o Convento dos Religiozos de Saõ Francisco, onde eu terceiro Escripturario abaixo assignado, fui vindo com o Almoxarife da Fazenda Nacional Antonio Maria (Q)uardim, para effeito de se proceder a Inventario nos bens pertencentes ao dito Convento de Saõ Francis- 
co, na conformidade da Portaria de tres de Dezembro do corrente, ahí se procedeo na forma seguinte: bens existentes: hum relojo da Torre, hum Sino grande, hum me(aõ), hum pequeno, hum do toque das duas horas, ehuma Sineta na Portaria, a propriedade do mesmo Convento com suas portas, ejanellas competentes, ficando outro (f)im as Tribunas, janellas, e porta do Coro da communicaçaõ da Igreja, feixadas, epregadas com segurança, como determina amesma Portaria, cujas chaves (fíz) dellas entrega ao Porteiro do Curso Juridico, Carlos Luíz Godinho, de cuja recepçaõ abaixo se assigna. E para constar, lavrei oprezente Termo por tres vias, que assigno com os acima nomeados.

\section{Antonio Maria Quar(t)i(m) \\ Almoxarife \\ Carlos Luis Godinho \\ Manoel Barboza da Silva}

Contudo, apesar de as portas de comunicação entre a Igreja e o edifício do Curso Jurídico estarem trancadas, os estudantes comumente violavam os limites entre os prédios. É na voz do Francisco de Paula Leme (documentos AMI 1828-31/0087 e 0087v. Anexo: documentos 11 e 11verso, respectivamente) que a insatisfação dos franciscanos se manifesta. O ofício, datado de 10 de dezembro de 1828, ou seja, apenas uma semana depois da entrega do edifício, mostra que os franciscanos não tolerariam mais violações do espaço religioso.

Documento $11 \quad$ ami 1828-31/0087

[[10 Dezembro de 1828]]

[[Carimbo do Archivo da Faculdade de Direito, com rubrica Barros]]

1

Copia fiel

Illustrissimo Senhor Marchar

Saeristia

Sacreistia deSam francisco

10 de dezembro de 1828

Muito meo A(m)ádo E Senhor, Paso a dizer aUossa Excellencia que quando o menistro deSatanas deu emtrada A Uossa Eixcellencia Eo presidente do gouerno desta prouinsia para dentro do defunto Comuento que ya, o tinha per dido com aSua far(s)a doutrina ya o prezidente E Uossa Eixcellencia deraõ prouidensia de Ser fechado e deuedido a Sam Cristi com aygreya, para, os estudantes nam empurtunarem os menistros deDeos $\mathrm{Na}$ Selebrasam do agusto Sacreficio do Altal Sagrado epara tudo o mais que pertense de adeministrasaó do Sacramento para os fieis. 
E Agora como conheso De muittos annos aestimavel pesoa de Vossa Excellencia que Sempre foi Religizo, E cotolico E de dotrina Solida eSabe que auida, he emprestado eque temos dois Caminhos para Seguir desta mortal Uida E como Deos foi Servido trazerme por milagre que alcamsome o meu seNhor Serafico Padre Sam francisco de asis de nam ficar aleyado de huma Coxa foi, a Causa de eu, uir Comprir com o meu, uoto que a dois annos e 88 dias que o Santo Padre me uestio com o Seu abensoado abito eprendeume com o Seu Cordam para Sempre e me entregou as chaves da Sua Igreya e Sam cristia Ecomo Uossa Excellencia em outro tempo pela bondade ya me çervio numa cousa muito em Sinificante, Poriso me anima, a pedir aUossa Eixcellencia, Pelo Amor deDeos E de Nossa May Maria Santisima das Dores que está de guarda da mesma Sam cistia a de Sua Igreya Nam bula nem deixe nimguem bolir da diviza que Uossa Excellencia, eo P e o presidente foram Seruidos mandar fechar pois tem no defunto Comuento muito Comodo de fazer mais de dez aulas pois Nam ha Capela por pequena que Seya que nam tenha Samcristia quato mais esta que he como Vossa Eixcellencia, melhor tem visto he, o que Se me oferese a pedir Aestimavel Pesoa deVossa Eixcellencia, aquem dezeyo logre felis Saude Em grasa de

Documento $11 \mathrm{v}$ ami $1828-31 / 0087 \mathrm{v}$

$1 v$

de Deos poderozo para tudo o que for para aomento da Santa Religiam Catolica e bem da Saluasam das Almas Espero que este meu petitorio, que faso aVossa Eixcellencia Seya, atendido, por aquele Eaquela aquem peso por todos enam por este em diguino Einut(é)l escrauo E do Nato Samcristaó

\section{Francisco de Paula Leme}

A carta, dirigida ao diretor do Curso Jurídico, nove meses depois de começadas as aulas, traz a voz de alguém incomodado pelos acontecimentos recentes, reclamando da falta de respeito dos estudantes para com a igreja, quando uma rotina de religiosidade culminou em uma súplica em favor de não deixar que violassem os limites impostos entre o Convento, já morto (linha 11: defunto), e lugar das aulas, e a igreja e coro. Além disso, Francisco de Paula Leme apela à religiosidade de Rendon e aos favores que este já fizera ao sacristão.

É interessante notar, também, que o sacristão diz que foi satanás quem deu margem à transformação do Convento no espaço para o Curso: 'Satanás deu entrada para que Vossa Excelência e o presidente do governo desta província adentrassem no defunto Convento, que já o tinha perdido com a sua falsa doutrina'. De certa maneira, a afirmação parece não considerar que o próprio Rendon foi responsável pela escolha do Convento como locus ideal para a Academia. Ao contrário dos jesuítas, para quem civilização e 
cristianismo andavam lado a lado, já que se ensinava a ler e escrever, para juntamente passar a doutrina cristã, o sacristão parecia crer que o conhecimento em assuntos não referentes à doutrina cristã apenas traria coisas ruins, indignas de andar lado a lado com a fé. A este respeito, Campos (1954: 301) comenta que sem a menor reserva, (...) a IGREJA CATÓLICA construiu sòlidamente a base fundamental de tôda a cultura universitária à qual depois tem dado contribuição constante e devotada, através de seus colégios e de suas universidades. Foi assim em São Paulo, com o Convento Franciscano, como também em Olinda, com a cessão do Mosteiro de São Bento para a criação do curso jurídico.

Em ofício ao Governo Imperial, datado de 9 de dezembro de $1828,{ }^{17}$ o diretor Rendon relata que havia recebido uma carta do padre guardião, no dia 2 de dezembro, pedindo-lhe que fosse receber o Convento no dia seguinte, às $4 \mathrm{~h}$ da tarde. Diz ter mandado oficiar ao almoxarife que fizesse, em triplicado, um inventário dos pertences do Convento, deixando com o padre apenas os livros e o relógio da torre. Reitera que pediu ao vice-presidente que mantivessem trancadas as portas que granjeavam acesso ao coro da Igreja e da lateral que dava entrada para a mesma, ficando para o Curso o campanário e a sacristia, os quais eram separados do templo. No entanto, diz que a porta para o coro foi trancada, não sendo possível selar a porta de baixo, que dava entrada para a sacristia, já que o padre guardião havia guardado os móveis grandes na sacristia e no corredor dela, ficando apenas com uma separação com grade entre o curso e o corredor para a sacristia. Reitera dizendo que a sacristia devia ser incorporada ao Curso Jurídico, porque era um grande salão com janelas em três faces, muito próprio para uma aula, e dava para a cerca do edifício, pertencente à nação. Dizia que a Ordem Terceira não necessitava da sacristia, porque já tinha sua própria, entre uma e outra igreja. Continua o relato dizendo que no dia seis de dezembro estivera no Convento com o vice-presidente e achara um donato no governo da Igreja, o qual era responsável por cuidar dos móveis até a decisão do presidente Provincial. Então continuava relatando que não sabia se a Ordem Terceira ficaria com a Igreja, porque já possuíam uma. Dessa forma, pedia para a Igreja ser entregue a uma numerosa irmandade denominada São Benedito. Acrescentava que nisso não tinha entrado, por não lhe pertencer, mas que a sacristia deveria ficar fora da igreja como desnecessária a ela, porém precisava para o Curso Jurídico. Rendon relatava ter solicitado ao vice-presidente que mandasse tirar a planta do edifício e cerca para enviar a José Clemente, e pedia licença para poder pedir o que lhe parecesse útil em relação a mudanças no que fosse conveniente. Segundo Rendon, o Convento acomodaria muitas faculdades e que o cercado deveria ser retalhado em duas ruas, pois dariam muito valor ao terreno, o qual era muito extenso e o reputava metade da cidade.

\footnotetext{
17 A datação do documento contradiz a informação "3 do corrente", que se refere à data da entrega do Convento, ou seja, 3 de dezembro de 1828 .
} 
Francisco de Paula Leme remete um ofício ao diretor do curso jurídico, datado de 14 de dezembro de 1828, no qual pede, com extrema humildade, que o Diretor não pensasse somente no público, mas que também desse atenção à Igreja e que cuidasse para que houvesse o toque do sino religioso para os fiéis vivos e os defuntos, voltando a pedir que o sineiro lhe desse a chave ou abrisse a porta às quatro horas da manhã e às três horas da tarde, porque o "desgraçado" sineiro se recusara a soar nas horas pedidas, por não ter nenhuma obrigação com a Igreja. Leme pedia perdão por importunar e assinava, humildemente, como um indigno escravo e inútil criado sacristão.

Em 18 de dezembro de 1828, o diretor do curso jurídico diz a José Clemente Pereira que havia enviado um ofício em 10 do corrente, remetendo uma carta do donato Francisco de Paula Leme, que ficou morando na sacristia (no original "caristia") que havia sido dos franciscanos. Juntamente com o ofício, envia a carta de Francisco de Paula Leme, na qual pede que o sineiro toque os sinos ou lhe entregue as chaves. Chama-o de fanático, e fanático façanhoso, o qual, querendo ficar na sacristia, não convinha que germinasse ali "peçonhenta semente". Diz ainda ao almoxarife relator que, em 17 de dezembro, alguns vidros das vidraças das aulas que deitava para o pátio haviam sido quebrados, fazendo suspeitar daquele "fanático e de seus consócios", já que vidros de casas particulares não foram quebrados. Pede que o caso seja levado à presença do Imperador e espera que sejam transmitidas ordens sobre o que fazer.

Manuel Joaquim de Ornellas, vice-presidente da Província de São Paulo, em ofício $^{18}$ a José Clemente Pereira, datado também de 18 de dezembro de $1828,{ }^{19}$ menciona que recebera determinação do Imperador para que o Governo da Província de São Paulo verificasse a entrega ao diretor do Curso Jurídico do Convento de São Francisco sem demora, já que havia sido oferecido pelo Provincial dos Menores Observantes. Em seguida, diz já ter comunicado imediatamente ao guardião do Convento, sendo que este nenhuma dúvida havia oferecido, apenas se achava enfermo e não queria deixar o Convento para se tratar em outro lugar, mas que tão logo estivesse curado, não hesitaria um momento em satisfazer o que se lhe ordenava. O vice-presidente enviou cópia do ofício do guardião e acrescentou que estava sensibilizado com a doença do Frei, no entanto as ordens imperiais seriam prontamente cumpridas, assim que o guardião estivesse restabelecido. Acrescenta ainda que o guardião comunicara-lhe sobre a biblioteca que fora legada ao Convento pelo falecido Bispo Funchal e esperava deliberação do Imperador para que dissesse o que haveria de ser feito, sem, todavia, atrapalhar a entrega do Convento.

18 Ofício não encontrado no arquivo da FD.

19 No final da cópia, há os seguintes dizeres: “(Nota: /Parece que a data deste officio está errada./Deve ser Novembro e não Dezembro porque em/3 de Dez. o Conv. Já foi entregue e em 17 de/ Dez. o Governo já providenciára sobre a Bi-/bliotheca.) 
Considerações finais

A entrega do Convento dos Franciscanos ao Curso Jurídico em 1828 constituiu-se mais como um ato de tomada do edifício do que de cessão voluntária. Por um lado, o diretor do ainda não implantado Curso Jurídico de São Paulo, José de Arouche de Toledo Rendon, escolheu o edifício do Convento e sacramentou seu destino, sem comunicar nada às autoridades eclesiásticas proprietárias do prédio. Por outro lado, aos comunicados da escolha de seu edifício, recebidos via correspondência imperial, e sobre a necessidade de sua voluntária cessão, os franciscanos imprimiram morosidade ao processo a ponto de haver um ultimatum por parte da Administração Imperial. Ademais, a demora em desocupar o Convento provocou a insatisfação do Diretor do Curso e, ao mesmo tempo, ressentimento nos frades que residiam no edifício. A carta do sacristão residente é explícita ao declarar que a escolha do Convento para ser sede da Academia só podia ter sido obra sob influência de satanás. O sacristão, disposto a tolerar a perda do edifício do Convento, mostrou-se muito pouco condescendente em relação aos limites entre a sacristia e a escola e expõe sua insatisfação logo no primeiro incidente. Toledo Rendon, por sua vez, tratava o sacristão Francisco de Paula Leme como um 'fanático' que, com seus consócios (Campos 1954: 319), ocupara a sacristia indevidamente. ${ }^{20}$

Apesar de todos os esforços, o Convento transformou-se na sede do Curso Jurídico de São Paulo, posteriormente Faculdade de Direito de São Paulo, sendo depois incorporado à USP. Os franciscanos tentaram, no século xx, em disputas judiciais, reaver o Convento, sem, no entanto, lograr êxito.

\section{Referências}

ADORNO, Sérgio. Os aprendizes do poder: o bacharelismo na política brasileira. Rio de Janeiro: Paz e Terra, 1998.

ARAUJO, Gabriel Antunes de et al. Alguns manuscritos do século XIX da Faculdade de Direito do Largo de São Francisco. Cosmica, n. 37, 143-79, 2007.

BELLOTTO, Heloísa Liberalli. Glossário das espécies documentais. In: ARRUDA, José Jobson de Andrade (Coord.). Documentos manuscritos avulsos da Capitania de São Paulo (1644-1830). Catálogo 1. São Paulo: Imprensa Oficial/FAPESP, 2000.

20 Campos (1954: 319) menciona um ofício do diretor do Curso Jurídico, José Arouche de Toledo Rendon, a José Clemente Pereira, datado de 18 de dezembro de 1828, reclamando de prejuízos trazidos por Francisco de Paula Leme, o qual trata como um 'fanático' que ocupou a sacristia indevidamente, após a saída dos franciscanos. 
. Como fazer análise diplomática e análise tipológica de documento de arquivo. São Paulo: Arquivo do Estado e Imprensa Oficial do Estado, 2002.

CAMBRAIA, César Nardelli. Subsídios para uma proposta de normas de edição de textos antigos para estudos lingüísticos. In: RODRIGUES, Ângela et al. I Seminário de Filologia e Língua Portuguesa, 13-23. São Paulo: Humanitas, 1999.

CAMPOS, Ernesto de Souza. História da Universidade de São Paulo. São Paulo: Saraiva, 1954.

CENCIC, Monica Aparecida. Documentos Manuscritos da Faculdade de Direito da USP 18271829. 2009. Dissertação (Mestrado) - Universidade de São Paulo, São Paulo.

LEME, Pedro Taques de Almeida Paes. Informação sobre as minas de São Paulo e a expulsão dos jesuitas do Collegio de São Paulo. São Paulo: Companhia Melhoramentos de São Paulo, s.d.

MARTINS, Ana Luiza; Heloisa Barbuy. Arcadas: história da Faculdade de Direito do Largo de São Francisco. São Paulo: Melhoramentos/Alternativa, 1999.

NOGUEIRA, José Luís de Almeida. A Academia de São Paulo: tradições e reminiscências. 3. ed. São Paulo: Saraiva, 1977. v. 1.

OLIVEIRA, Marilza. Interface Lingüística Histórica e Filologia. In: HERNANDES, Maria Célia Lima. (Org.). Domínios da Linguagem V. São Paulo: Plêiade, 2005.

RÖWER, Frei Basílio. Páginas de História Franciscana no Brasil. Petrópolis: Vozes, 1941.

SPINA, Segismundo. Introdução à edótica. São Paulo: Cultrix/uSP, 1977.

VAMPRÉ, Spencer. Memórias para a História da Academia de São Paulo. São Paulo: Editora Instituto Nacional do Livro, 1977.

VENÂNCIO FILHO, Alberto. Das Arcadas ao Bacharelismo. São Paulo: Perspectiva, 2004. 


\section{Anexo}

\section{Documento 1:}

\section{BN16081828}

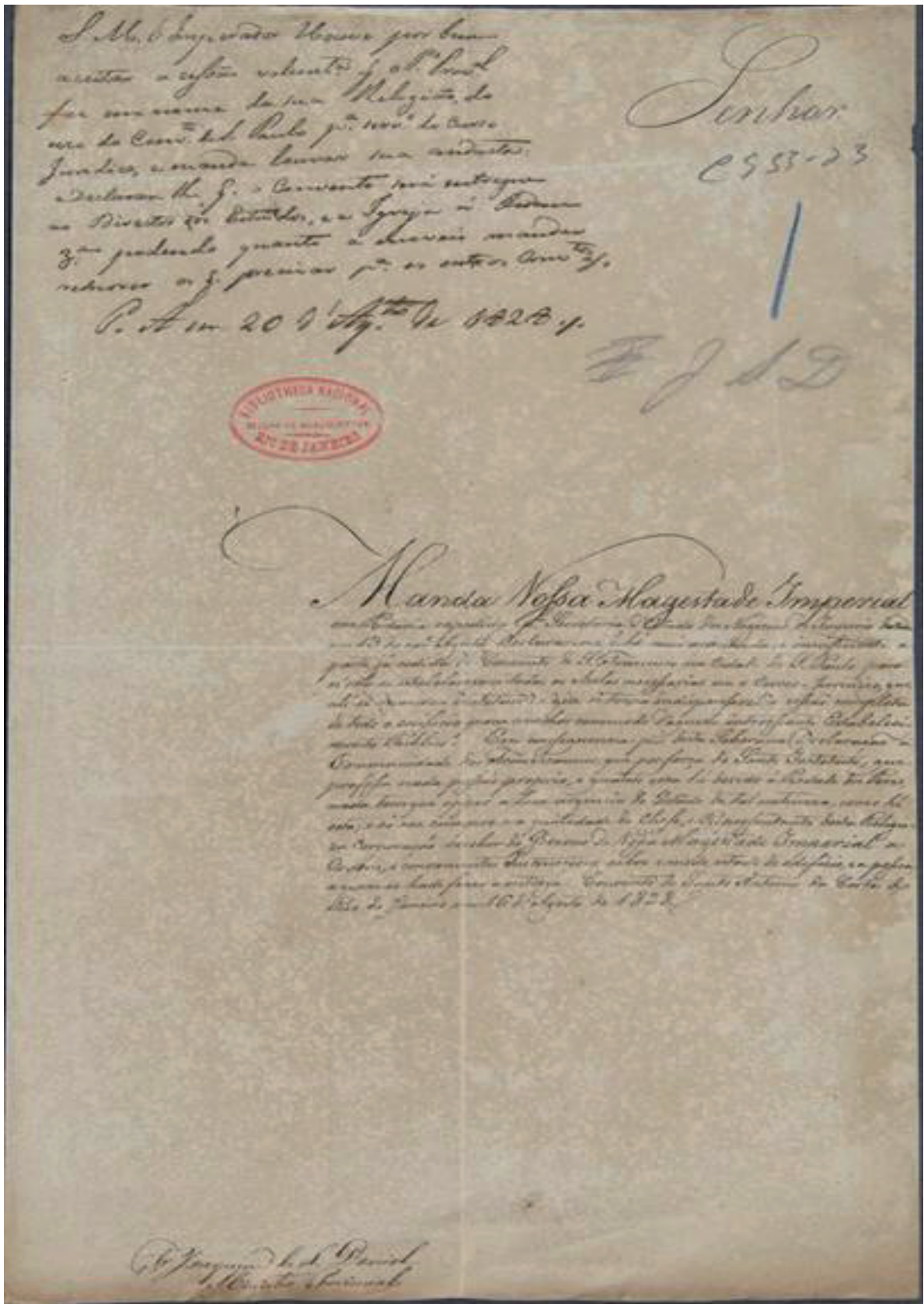




\section{Documento 2:}

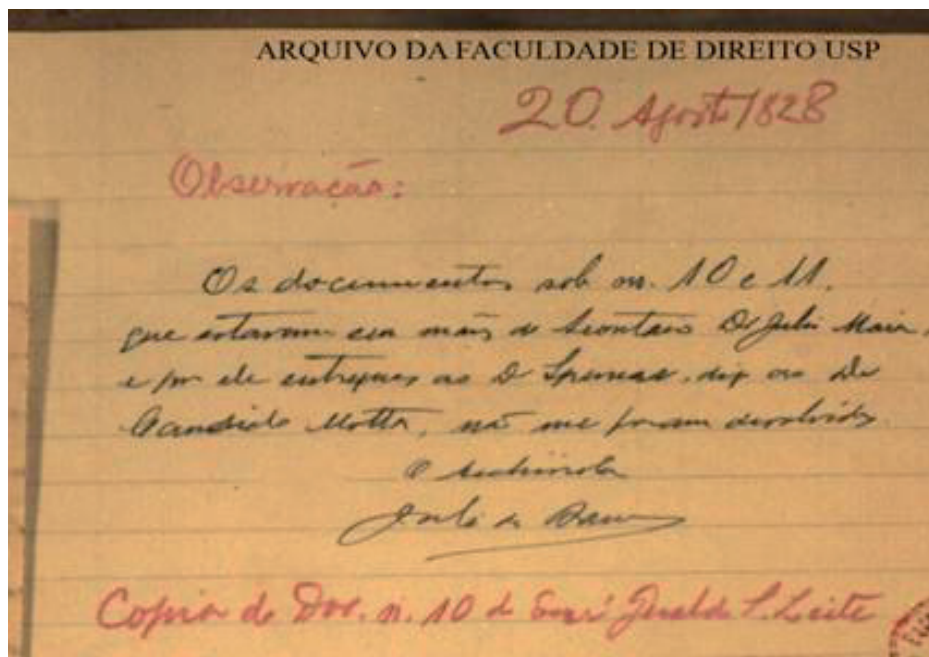

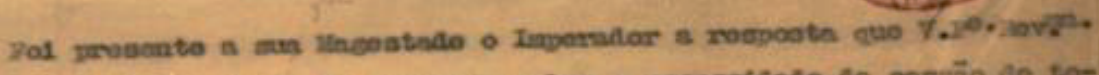

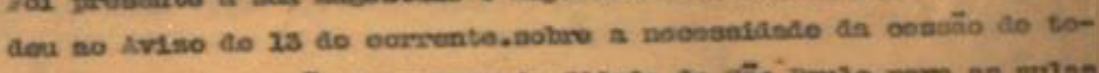

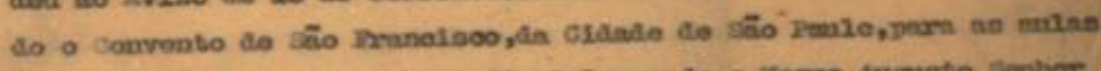

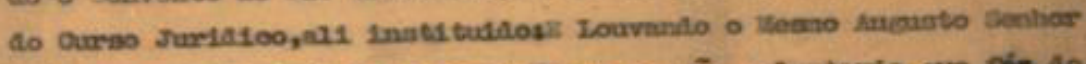

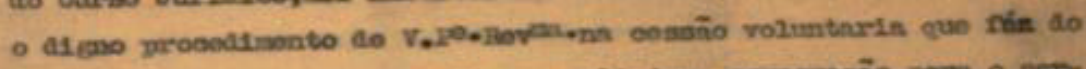

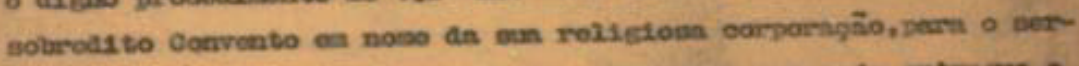

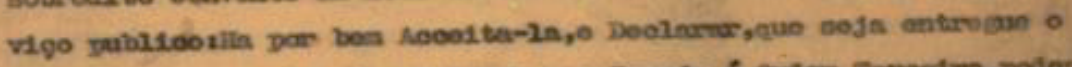

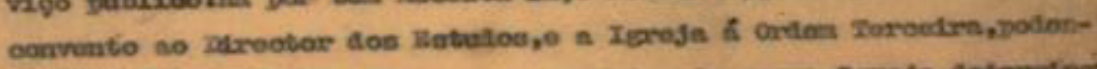

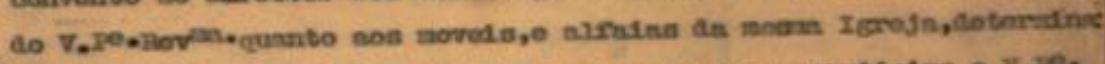

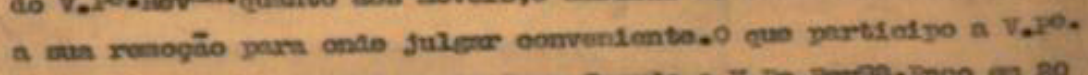

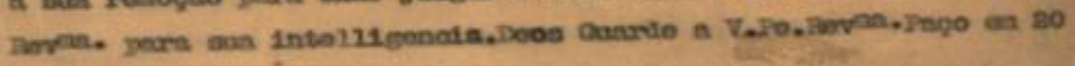

20 de Agosto de 1828.-Jozא́ Clemente Ferelra.Inr.Miniatro Provinotal a los lenores obeerventes:

$\frac{2}{3}$ 


\section{Documento 3:}

AMI 1828-31/0025

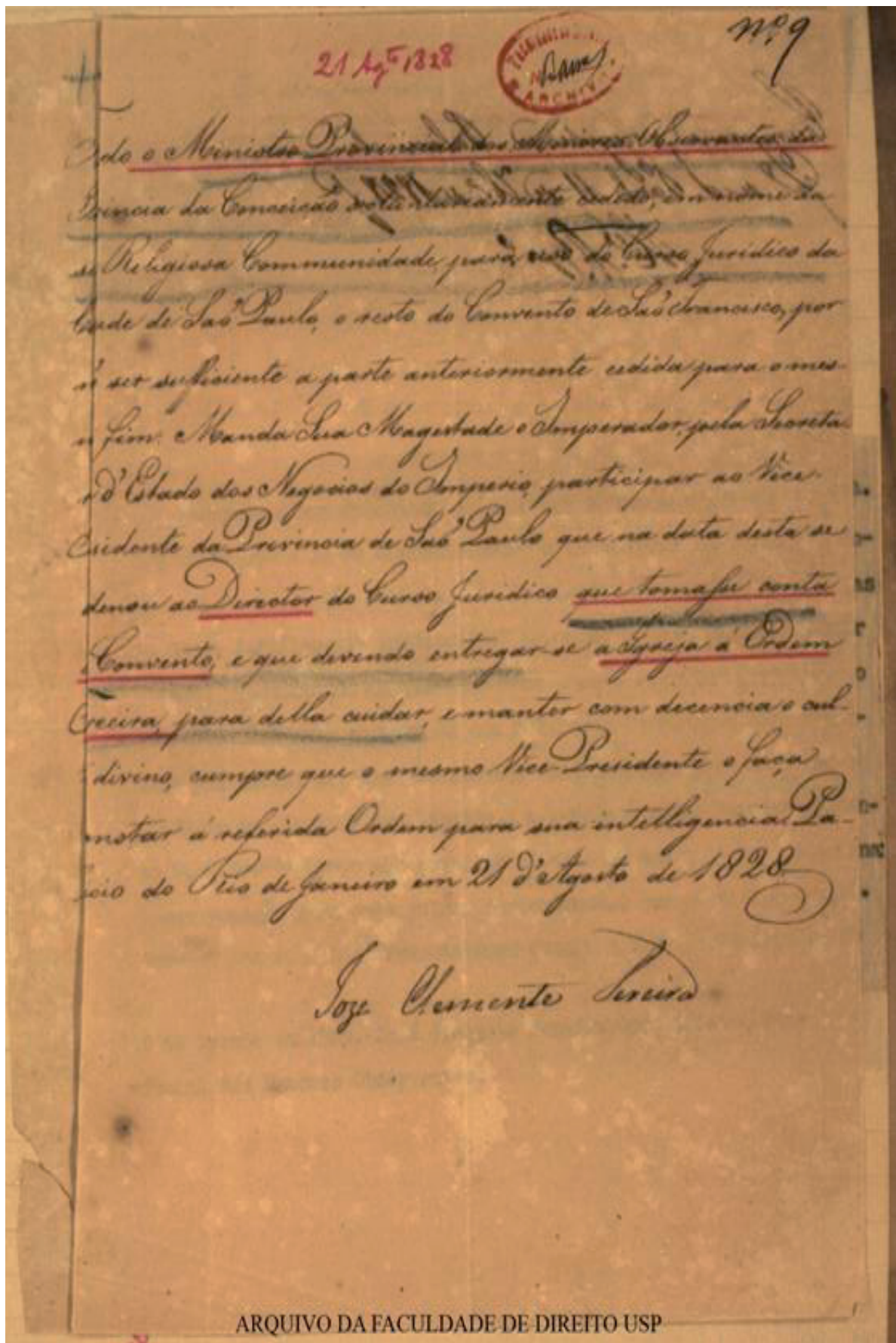


Documento 4: Arquivo dos Franciscanos

\section{f. Dack}

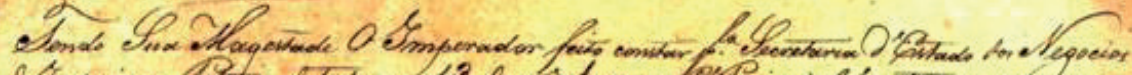

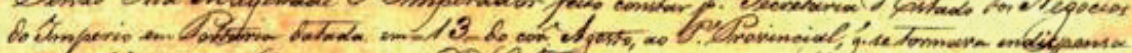

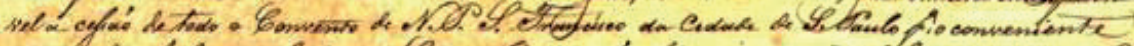

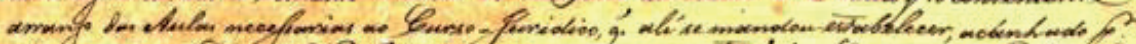

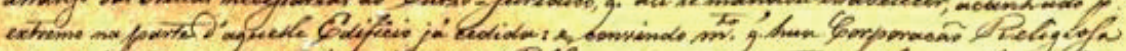

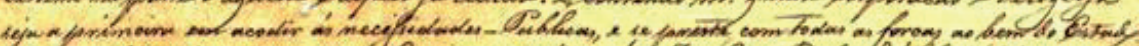

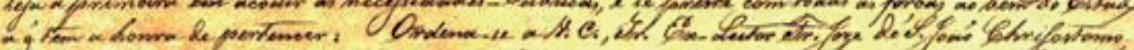

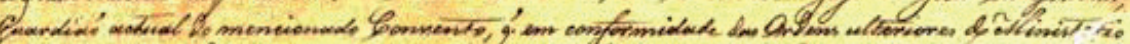

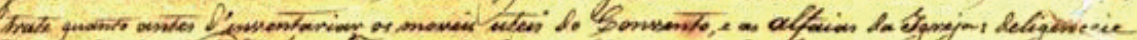

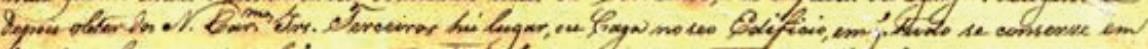

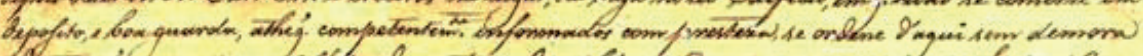

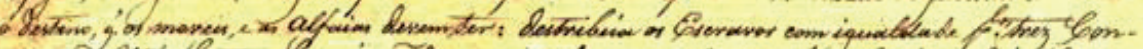

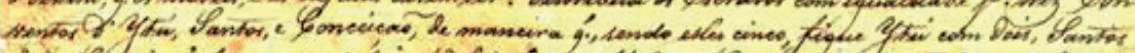

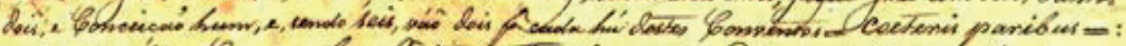

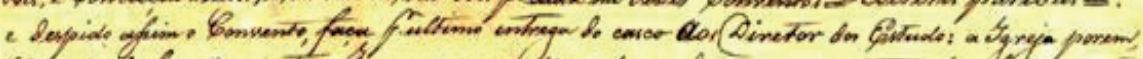

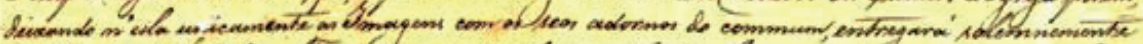

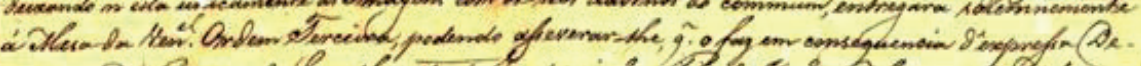

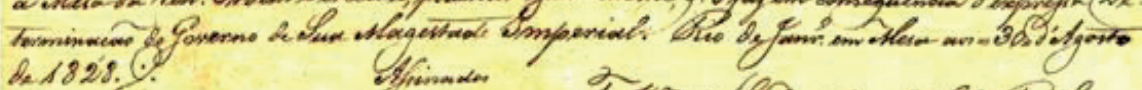
Le $1828 . \%$ Ofinisionden

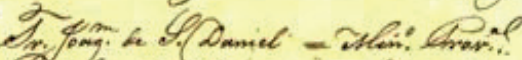

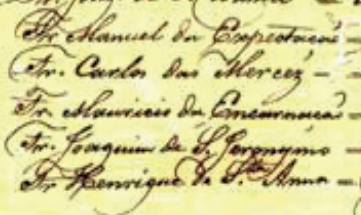

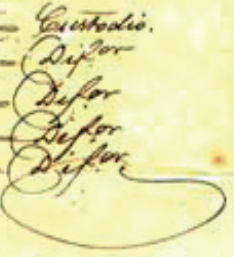




\section{Documento 5:}

AMI1828-31/0049

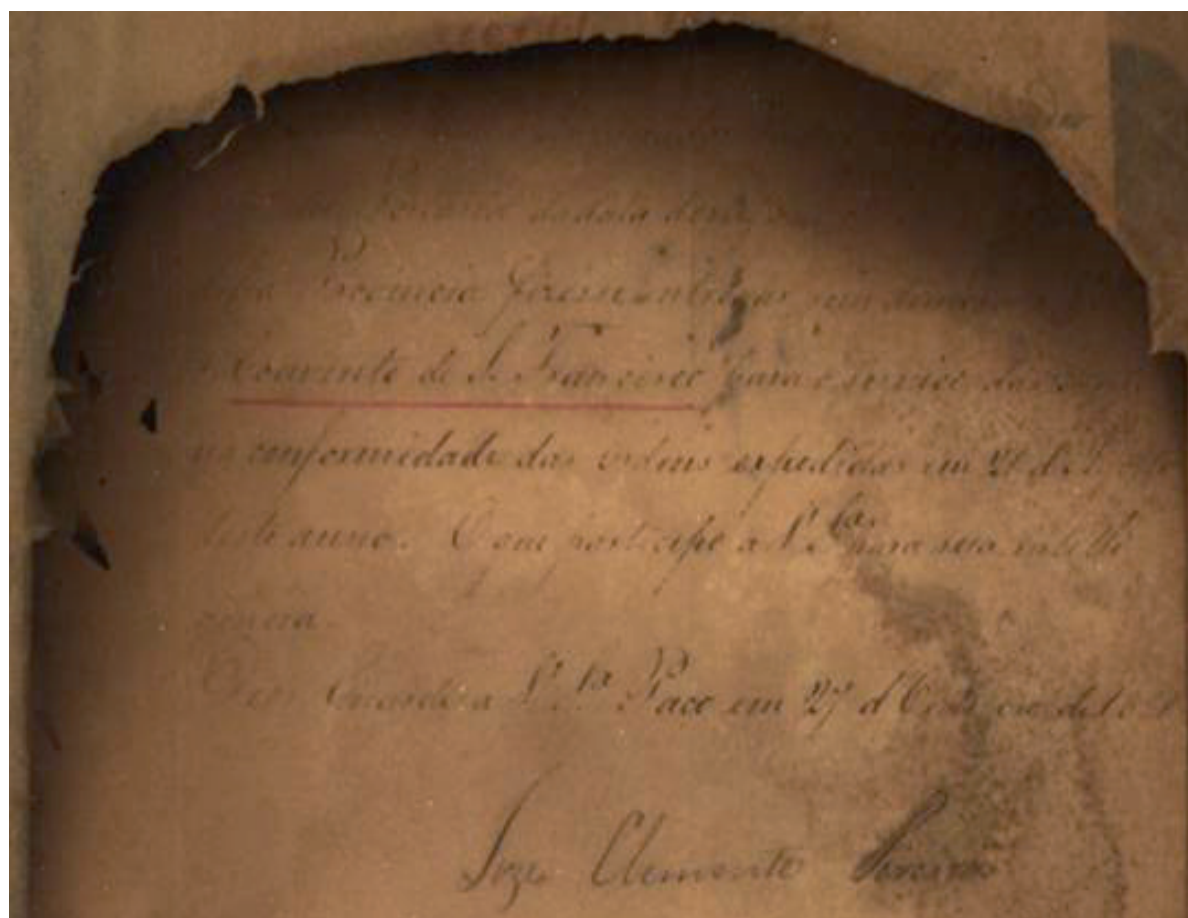


Documento 6:

AMI 1828-31/0055

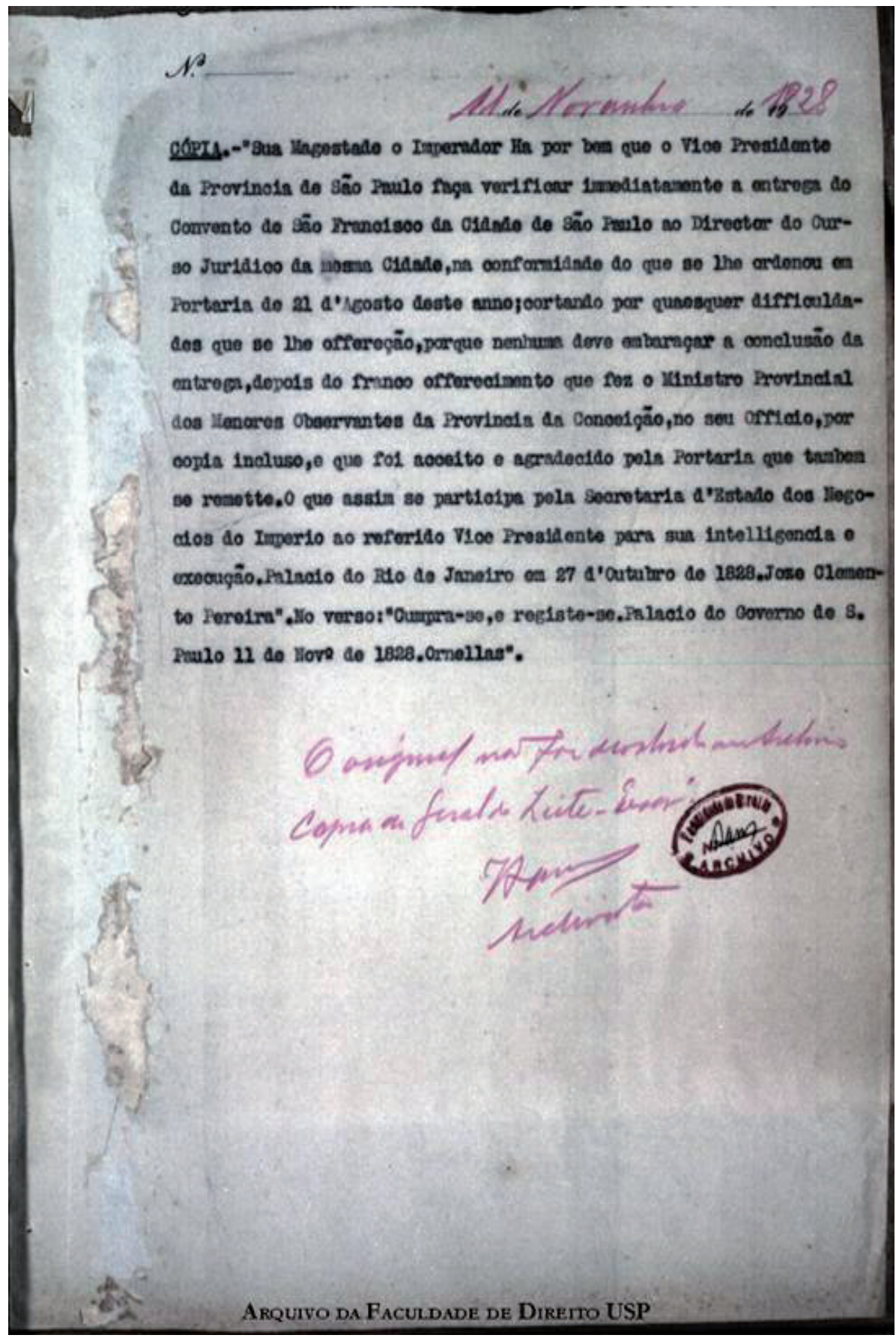


Documento 7:

AMI 1828-31/0071

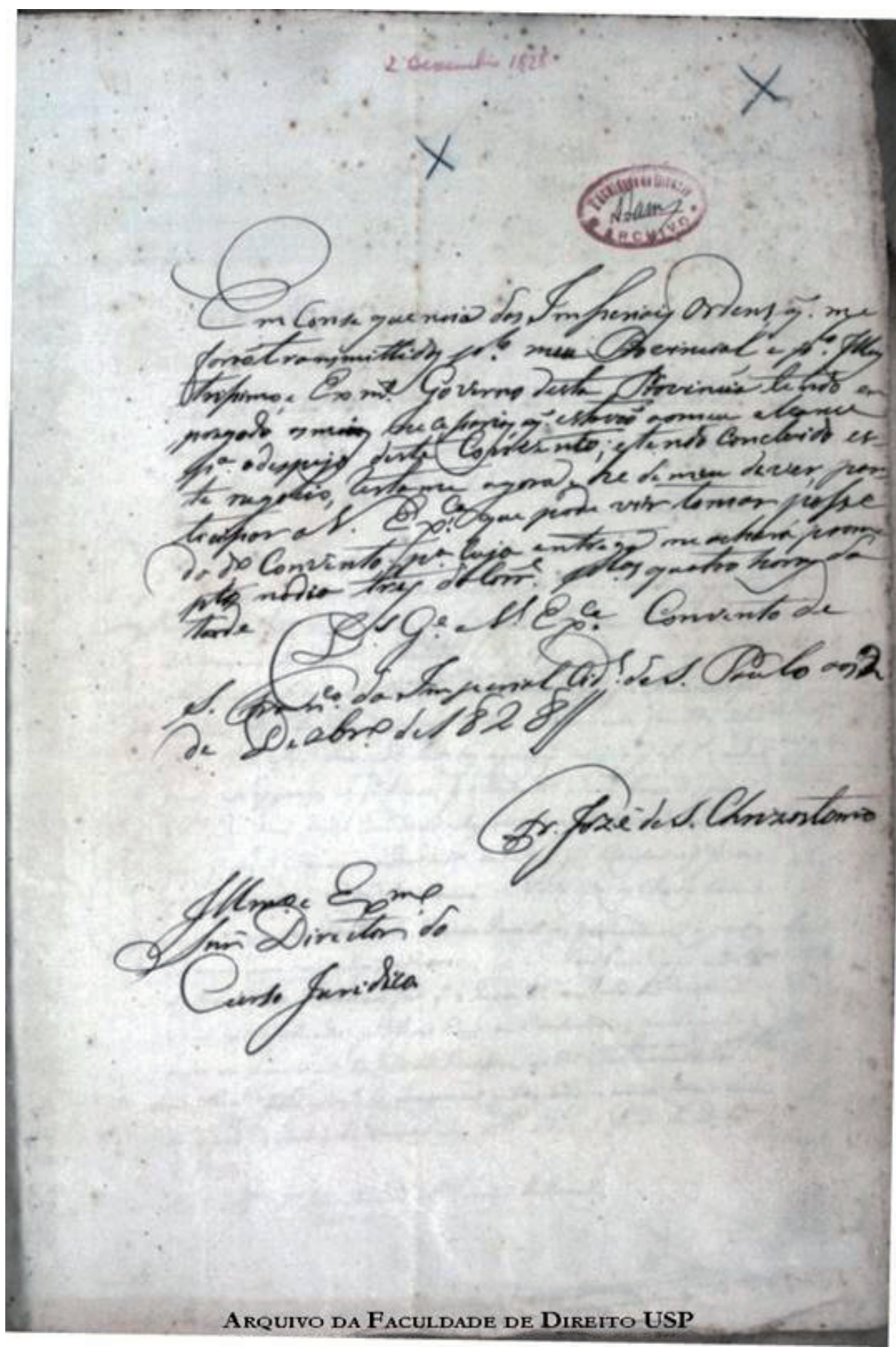


Documento 8:

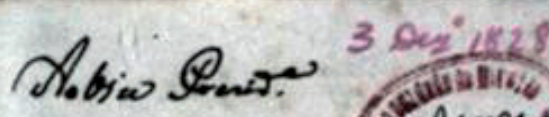

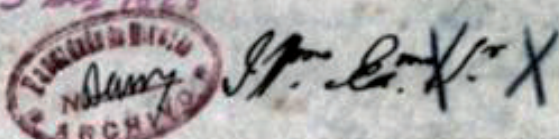

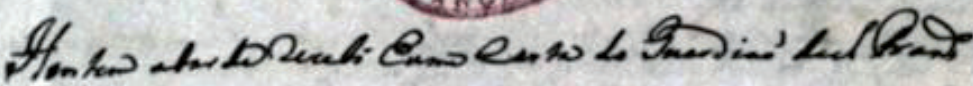

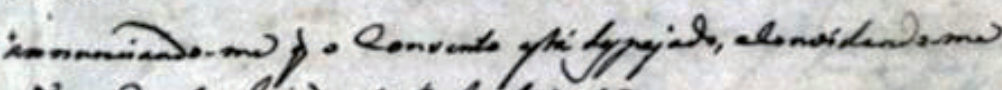

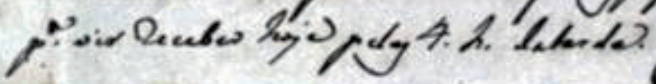

Cokbian Renry:

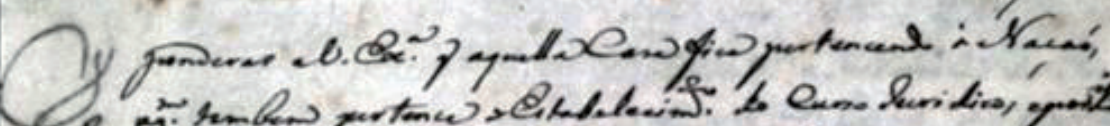

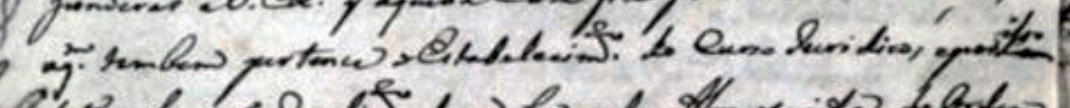

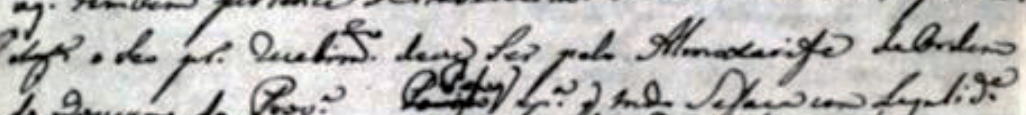

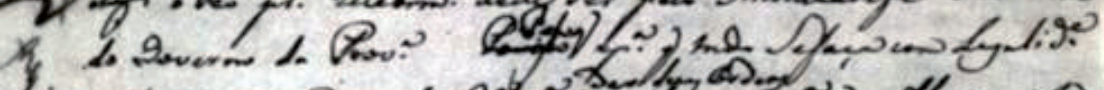

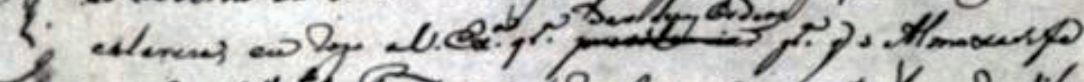

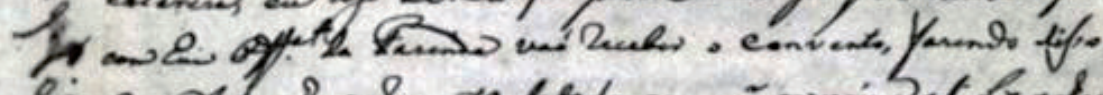

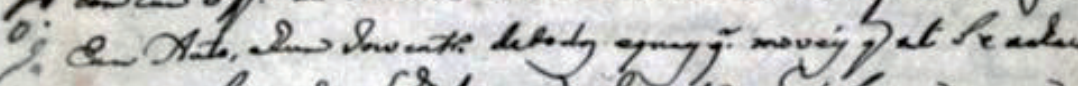

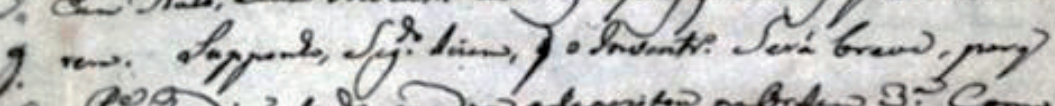

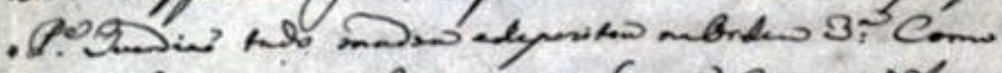

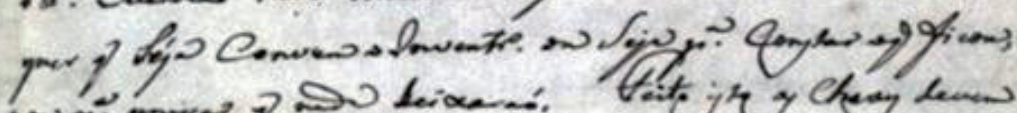

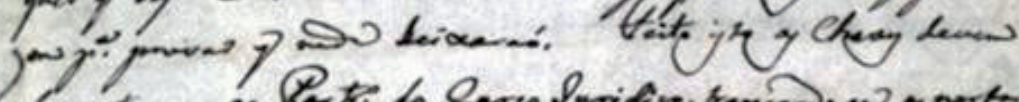

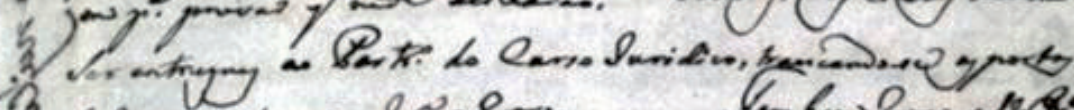

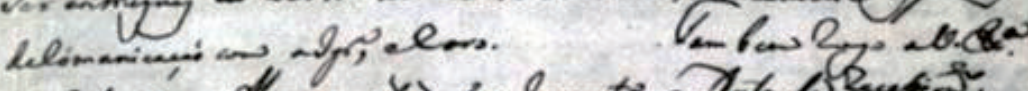

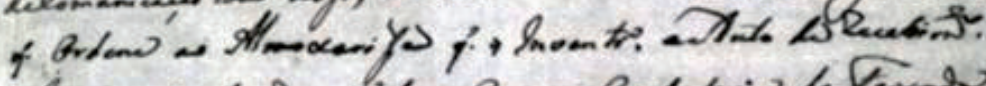

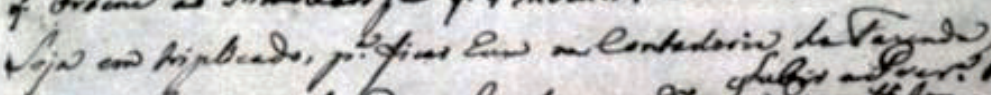

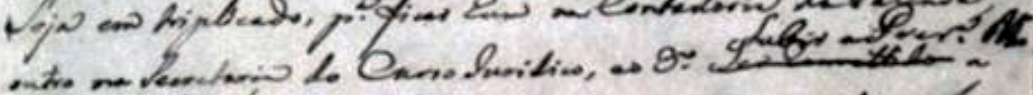

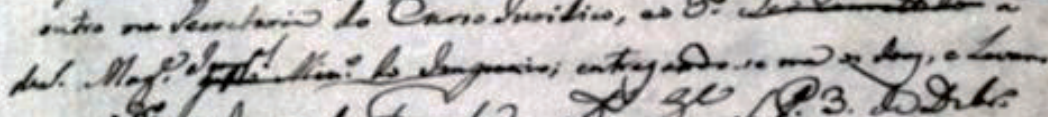

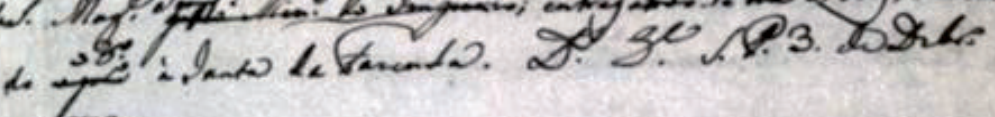

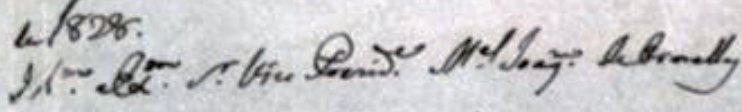


Documento 9:

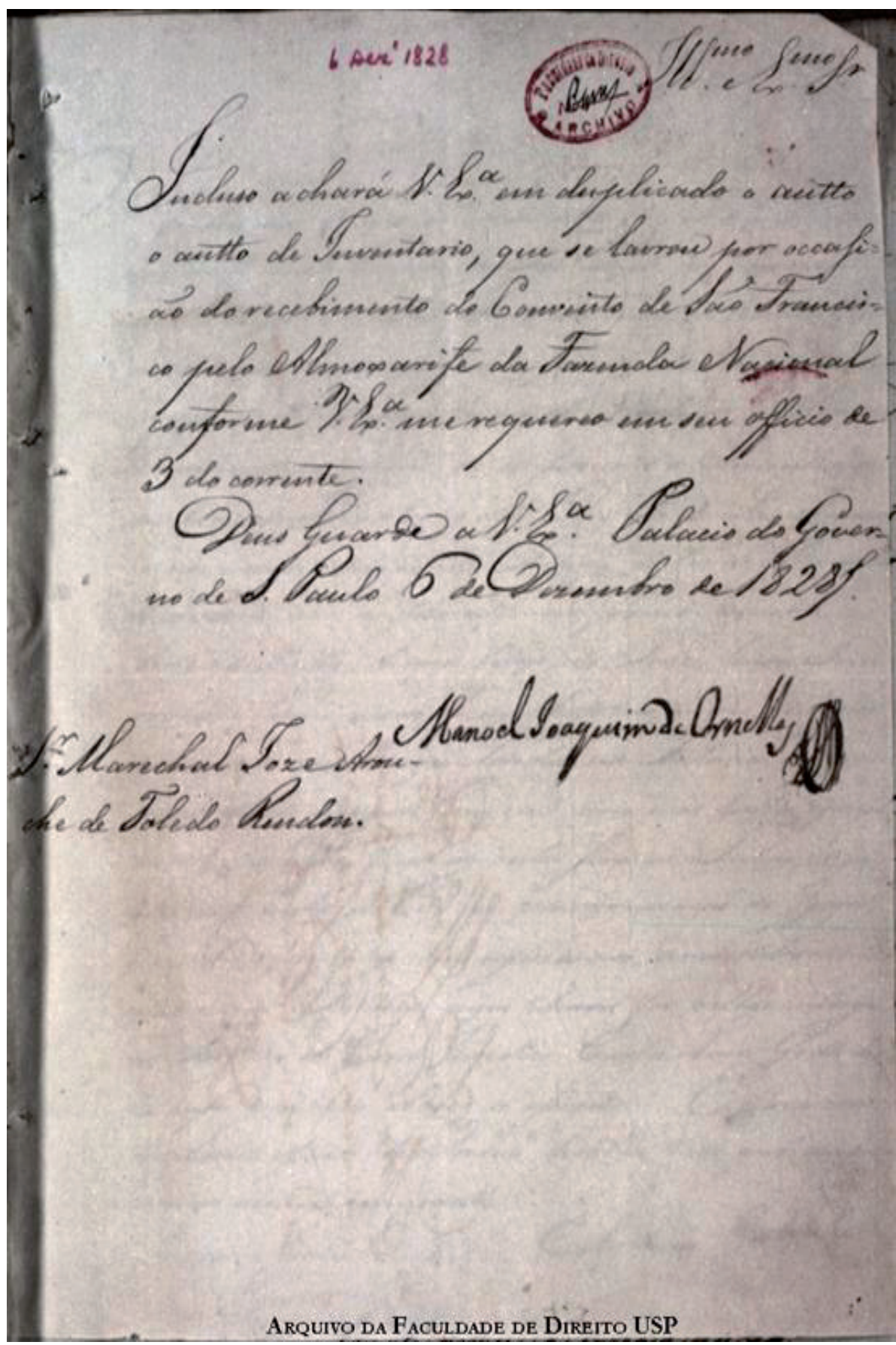


Documento 10:

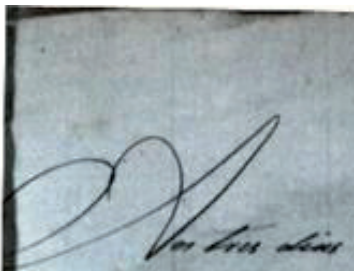

3 Der' $1828^{\circ}$

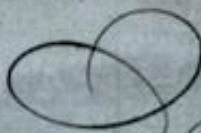

$\times$

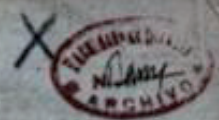

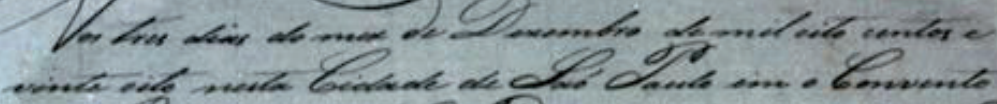

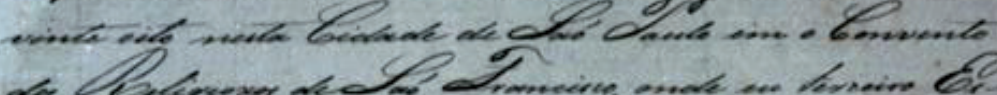

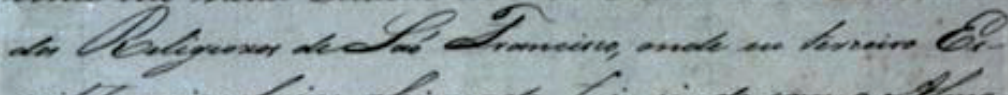

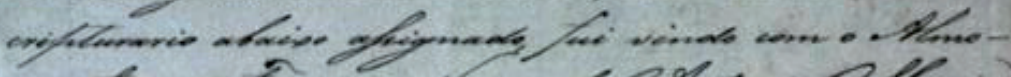

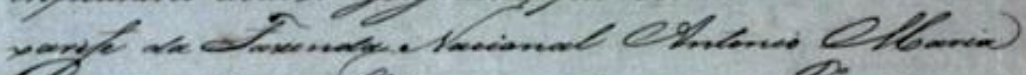

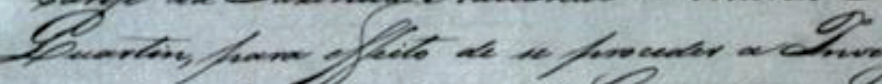

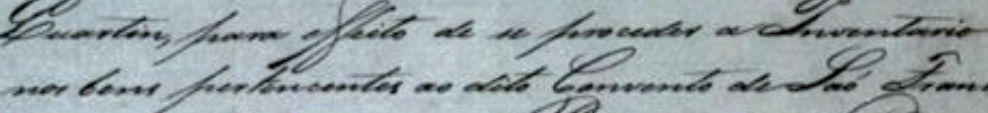

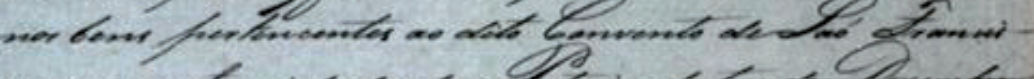

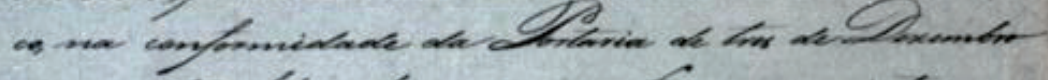

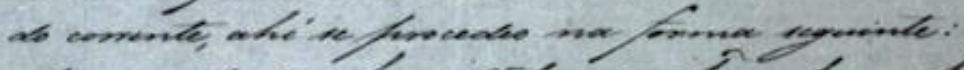

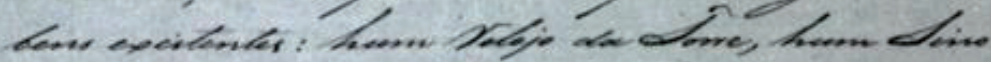

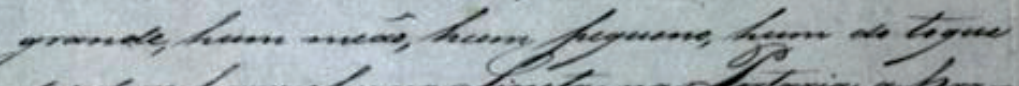

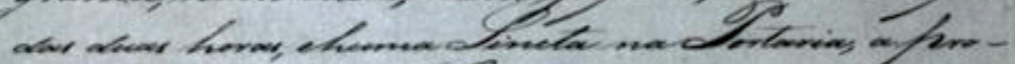

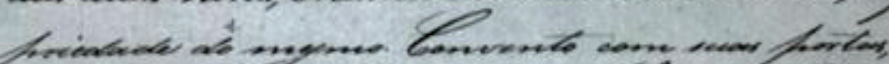

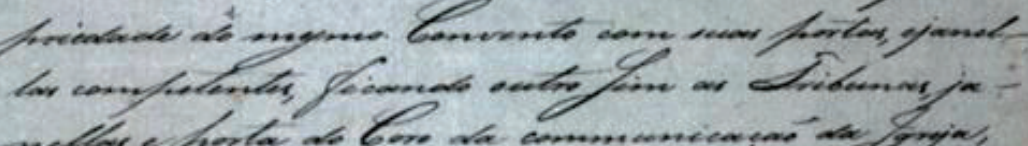

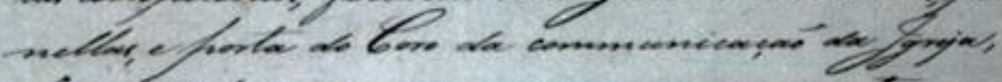

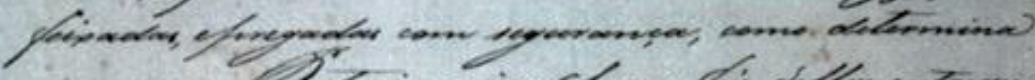

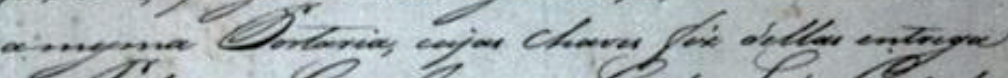

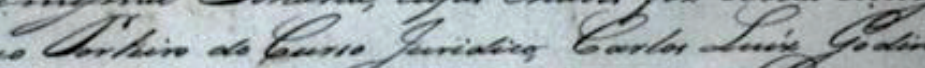

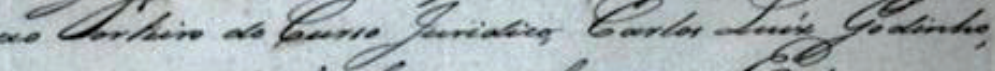

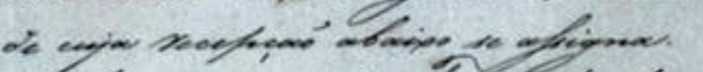

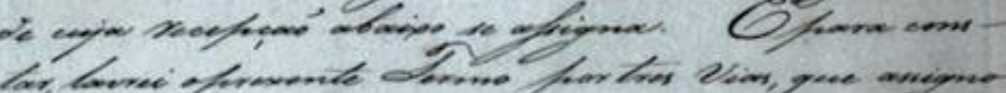

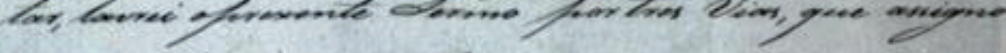

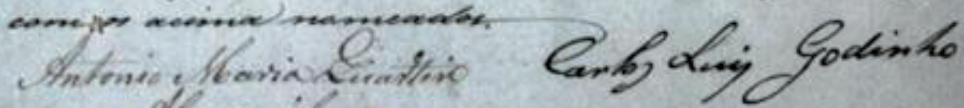
Hom. Dill

\section{Arquivo da Faculdade de Direito USP}




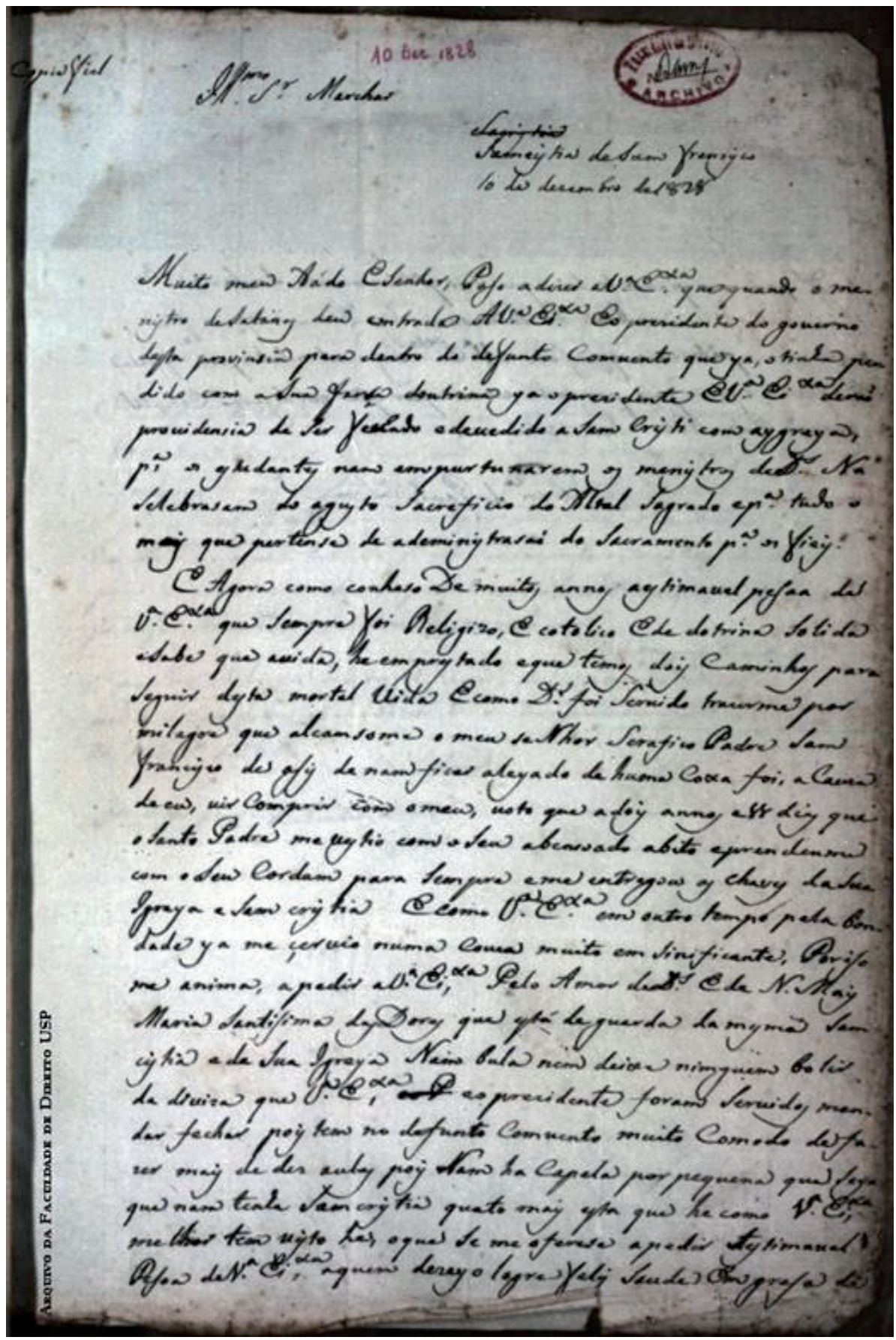


Documento 11 verso: $\quad$ AMI 1828-31/0087v

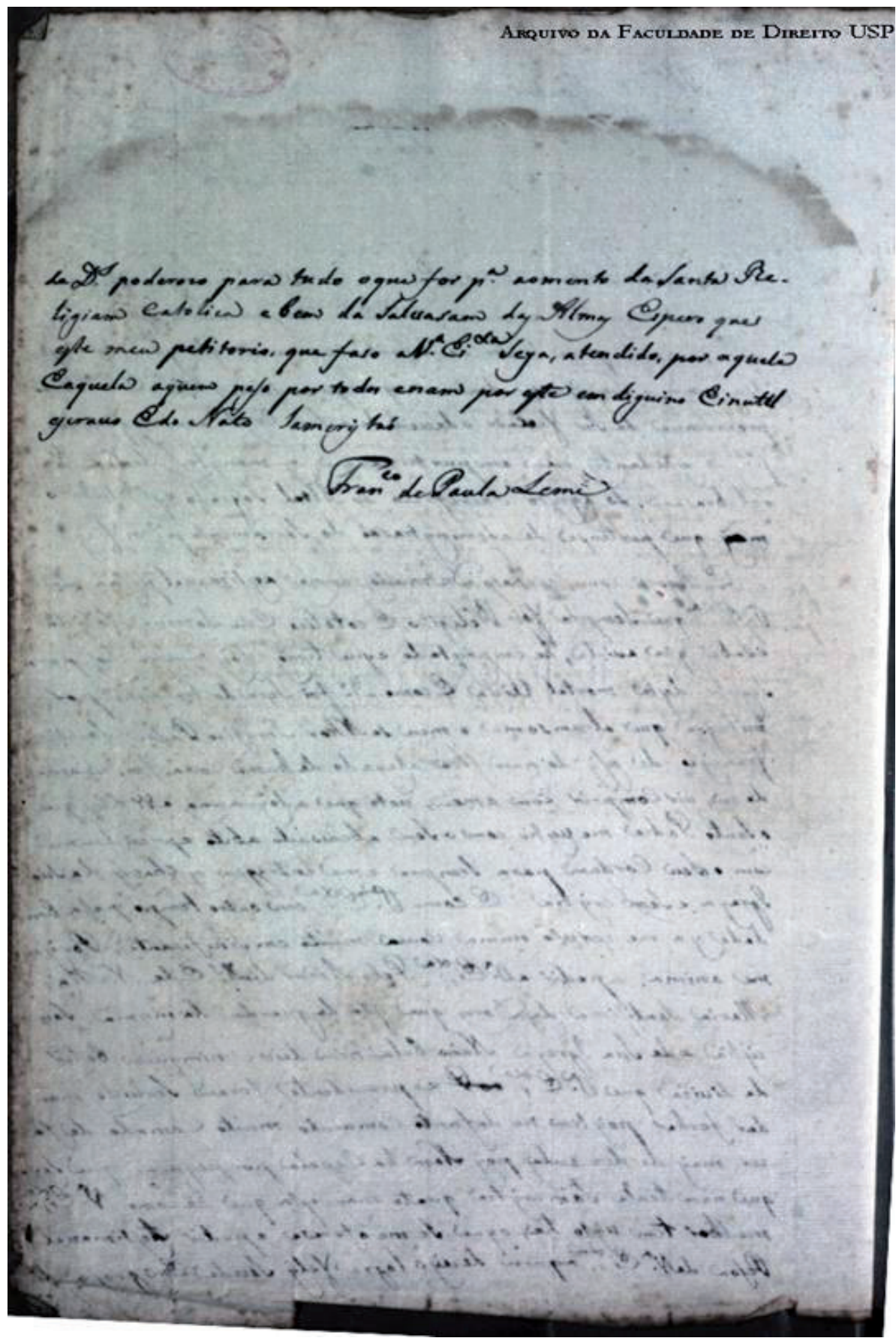

